\title{
Ecology, growth and management of black locust (Robinia pseudoacacia L.), a non-native species integrated into European forests
}

\author{
Valeriu-Norocel Nicolescu ${ }^{1} \cdot$ Károly Rédei $^{2} \cdot$ William L. Mason ${ }^{3}$ Torsten Vor $^{4} \cdot$ Elisabeth Pöetzelsberger $^{5}$. \\ Jean-Charles Bastien ${ }^{6} \cdot$ Robert Brus $^{7} \cdot$ Tibor Benčat $^{8} \cdot$ Martina Đodan $^{9} \cdot$ Branislav Cvjetkovic $^{10}$. \\ Siniša Andrašev ${ }^{11}$ - Nicola La Porta ${ }^{12}$ - Vasyl Lavnyy ${ }^{13}$ - Dejan Mandžukovski ${ }^{14} \cdot$ Krasimira Petkova $^{15}$. \\ Dušan Roženbergar ${ }^{7}$ - Radosław Wasik ${ }^{16}$ • Godefridus M. J. Mohren ${ }^{17} \cdot$ Maria Cristina Monteverdi $^{18}$. \\ Brigitte Musch $^{19} \cdot$ Marcin Klisz $^{20} \cdot$ Sanja Perić $^{9} \cdot$ Ljiljana Keça $^{21}$ - Debbie Bartlett ${ }^{22}$ - Cornelia Hernea ${ }^{23}$. \\ Michal Pástor ${ }^{24}$
}

Received: 15 August 2019 / Accepted: 1 November 2019 /

Published online: 6 April 2020

(C) The Author(s) 2020

\begin{abstract}
Black locust (Robinia pseudoacacia L.), a species native to the eastern North America, was introduced to Europe probably in 1601 and currently extends over $2.3 \times 10^{6}$ ha. It has become naturalized in all sub-Mediterranean and temperate regions rivaling Populus spp. as the second most planted broadleaved tree species worldwide after Eucalyptus spp. This wide-spreading planting is because black locust is an important multipurpose species, producing
\end{abstract}

Project funding: This study was not funded by any source but carried out voluntarily by a group of people (university staff, researchers, practitioners) interested in the ecology, growth and yield and management of black locust.

The online version is available at http://www.springerlink.com.

Corresponding editor: Zhu Hong.

Valeriu-Norocel Nicolescu

nvnicolescu@unitbv.ro

1 Faculty of Silviculture and Forest Engineering, Transylvania University of Brasov, 500123 Brasov, Romania

2 Forest Research Institute, Budapest 9600, Hungary

3 Forest Research, Northern Research Station, Roslin, Midlothian EH25 9SY, UK

4 Faculty of Forest Sciences and Forest Ecology, University Georg-August, 37077 Göttingen, Germany

5 University of Natural Resources and Life Sciences, Peter Jordan Str. 82, 1190 Vienna, Austria

6 INRA Centre Val de Loire, 45075 Ardon, Orléans, France

7 Biotechnical Faculty, University of Ljubljana, 1000 Ljubljana, Slovenia wood, fodder, and a source of honey as well as bio-oil and biomass. It is also important for carbon sequestration, soil stabilization and re-vegetation of landfills, mining areas and wastelands, in biotherapy and landscaping. In Europe, black locust is drought tolerant so grows in areas with annual pre-

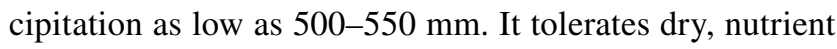
poor soils but grows best on deep, nutrient-rich, well-drained soils. It is a fast-growing tree and the height, diameter and volume growth peak before the age of 20 . It mostly regenerates vegetatively by root suckers under a simple coppice system, which is considered the most cost-effective management system. It also regenerates, but less frequently, by stool sprouts. Its early silviculture in production forests includes release cutting to promote root suckers rather than stool shoots, and cleaning-respacing to remove low-quality stems, reduce the number of shoots per stool, and adjust spacing between root suckers. In addition, early, moderate and frequent thinning as well as limited pruning are carried out focusing on crop trees. The species is regarded as

8 Technical University, Ul. T. G. Masaryka 24, 96053 Zvolen, Slovakia

9 Croatian Forest Research Institute, 10450 Jastrebarsko, Croatia

10 Faculty of Forestry, University of Banja Luka, Stepe Stepanovica 75a, 78000 Banja Luka, Bosnia and Herzegovina

11 Institute of Lowland Forestry and Environment, Antona Čehova 13d, Novi Sad 21000, Serbia

12 Fondazione Edmund Mach, Via E. Mach 1, 38010 S. Michele a/Adige, Italy

13 Department of Silviculture, Ukrainian National Forestry University, L'viv 79057, Ukraine

14 Public enterprise Makedonski sumi, Pero Nakov bb, Kosta Novakovic 12, Skopje 1000, Republic of North Macedonia 
invasive in several European countries and its range here is expected to expand under predicted climate changes.

Keywords Black locust · Ecology · Invasiveness · Climate change $\cdot$ Management

\section{Introduction}

Black locust (Robinia pseudoacacia L.) originates from the eastern half of the United States with two disjunctive areas: the larger source centered in the Appalachian Mountains, including Pennsylvania, Ohio, Alabama, Georgia and South Carolina States and the smaller source on the Ozark Plateau of Missouri, Arkansas, and Oklahoma. Outlying populations are also found in Indiana, Illinois, Kentucky, Alabama and Georgia (Huntley 1990). In native range, black locust is found in both pure and mixed stands as an associate of shortleaf pine (Pinus echinata Mill.), Table Mountain pine (Pinus pungens Lamb.), yellow poplar (Liriodendron tulipifera L.), white oak (Quercus alba L.), and northern red oak (Quercus rubra L.) (Huntley 1990).

The species has become naturalized (i.e., forming freeliving, self-sustaining populations in the wild unsupported by and independent of humans; Pyšek et al. 2009) in all sub-Mediterranean and temperate regions: Asia (thirteen countries, of which South Korea has over 1.2 million ha and China over 1 million ha), Africa (six countries),

15 University of Forestry, 1797 Sofia, Bulgaria

16 Faculty of Forestry, University of Agriculture, 31-425 Kraków, Poland

17 Department of Forest Ecology and Forest Management Group, University of Wageningen, 6700 Wageningen, The Netherlands

18 Consiglio per la ricerca in agricoltura e l'analisi dell'economia agraria, Viale Santa Margherita, 80, 52100 Arezzo, Italy

19 UMR 0588, INRA ONF BioForA, 2163 Avenue de la Pomme de Pin, CS 40001, 45075 Ardon, Orléans Cedex, France

20 Forest Research Institute, Braci Lesnej Street, no. 3, 05-090 Sekocin Stary, Raszyn, Poland

21 Faculty of Forestry, University of Belgrade, 1, Kneza Viseslava Street, Belgrade 11030, Serbia

22 Faculty of Engineering and Science, University of Greenwich, Central Avenue, Chatham Maritime, London ME4 4TB, UK

23 Faculty of Horticulture and Forestry, Banat's University of Agricultural Sciences and Veterinary Medicine, 300645 Timisoara, Romania

24 National Forest Centre, Forest Research Institute, T.G., Masaryka 22, 96092 Zvolen, Slovakia
Australia and New Zealand, South America (Argentina, Chile) (Keresztesi 1988a, b; Demené and Merzeau 2007; Tu et al. 2007; Contu 2012; Boer 2013; Cierjacks et al. 2013). Worldwide, its area increased from 337,000 ha in 1958 to 3,264,000 ha in 1986 (Keresztesi 1988a, b); in 2010, the estimated area of black locust plantations outside the native range was about 3 million ha (Schneck 2010). The species now rivals hybrid poplars (Populus spp.) as the second most planted broadleaved tree species in the world after Eucalyptus spp. (Rédei 2013b; Savill 2013; Wojda et al. 2015).

Black locust was the first North American tree species to be introduced into Europe in 1601 (Muller 2004; Hemery and Simblet 2014), although this date has been questioned by some authors (Cierjacks et al. 2013; Vítková et al. 2017). Seeds were sent by John Tradescant the Elder (English naturalist, gardener, collector and traveler, 1570-1638) to his friend Jean Robin (1550-1629), the gardener (or "arborist") of the French kings Henry III, Henry IV and Louis XIII, who sowed them in his garden (now the Place Dauphine in Paris) (Brosse 1977; Jardin des Plantes 2018). In 1636, his son Vespasien Robin (1579-1662) planted the first black locust in the King's Garden, now the Jardin des Plantes. This tree still exists and is the oldest tree in Paris and in Europe (Borde 2011). The year of introduction of black locust to other European countries (parks and gardens, as well as forests) is shown in Table 1.

Currently black locust occurs in forty-two European countries and is naturalised in thirty-two (Pyšek et al. 2009). It covers a total area of more than 2,306,000 ha (Brus pers. comm.) and is the most common broadleaved tree species on the continent. Countries where black locust accounts for at least 100,000 ha are Hungary, Ukraine, Poland, Romania, Italy, France, Serbia, Slovenia and Bulgaria (Table 2).

Initially, black locust was used as a park and garden tree and the first important forest use, in the nineteenth century, was to stabilize mobile sand dunes (Hungary, Romania, Austria-Hofmann 1861; Drăcea 1919) and to create shelterbelts (Austria-Hofmann 1861). Black locust has become an economically important multipurpose species in many parts of Europe, as a nitrogen-fixing species for waste land and surface-mine reclamation, for erosion prevention and control, for carbon sequestration, as windbreaks and shelterbelts, as an ornamental tree in parks, gardens, alleys, and as a street tree as it is tolerant of air pollution and salinity and thrives in the urban environment. If managed as short rotation coppice as in, for example, Austria, Croatia, Hungary, France, Germany, Greece, Italy, Poland, Slovakia (Paris et al. 2006; Facciotto et al. 2008; Rédei and Veperdi 2009; Borde 2011; Rédei et al. 2011; Maltoni et al. 2012; Steinegger and Reh 2013; Crosti et al. 2016; Giulietti 2016; Vítková et al. 2016), it is used for biomass production/bioenergy generation, and produces biomass up to 14 dry matter $\mathrm{tha}^{-1} \mathrm{a}^{-1}$ (Straker et al. 2015). In former mining 
Table 1 Year of introduction of black locust into different European countries

\begin{tabular}{lll}
\hline Country & Year of introduction of black locust in... & Forests \\
\cline { 2 - 3 } & Parks, gardens & \\
\hline Austria & $\begin{array}{l}\text { First individual planted by Emperor Leopold I } \\
(1656-1705) \text { in Vienna (Jacquin 1825) }\end{array}$ & \\
Bulgaria & Mid nineteenth century (Kirov 1886) & 1890 (Naydenov 2015) \\
Croatia & 1856 (Vuković et al. 2013) & 1880 (Đodan et al. 2018) \\
Germany & Ca. 1650 (Seeling 1997; Krausch 2001) & Ca. 1700 (Seeling 1997; Krausch 2001) \\
Hungary & $1710-1720$ (Rédei pers.comm.) & Beginning of nineteenth century (Rédei pers.comm.) \\
Italy & 1662 (Botanical garden of Padua) (Pignatti 1982) & Beginning of nineteenth century (Zucchini 1800) \\
Romania & Ca. 1750 (Drăcea 1919) & 1852 (Crăciunescu 1904; Drăcea 1919) \\
Slovakia & 1720 (Benčat pers.comm.) & 1780 (Benčat pers.comm.) \\
Slovenia & $1790-1800$ (Strgar 1992) & 1810 (Anko 1989) \\
Ukraine & End of eighteenth century (Kohno 2007) & Beginning of nineteenth century (Vakulyuk and Samoplavskyy 1998) \\
United Kingdom & $1640 \mathrm{~s}$ (Savill 2013) & Early nineteenth century (Savill 2013) \\
\hline
\end{tabular}

Table 2 Area of black locust in different European countries

\begin{tabular}{|c|c|c|c|}
\hline Country & Area (ha) & Sources & Notes \\
\hline Hungary & 465,000 & Rédei et al. (2017) & $\begin{array}{l}23 \% \text { of national forest area; from } 37,000 \text { ha in } 1885 \text {, } \\
109,000 \text { ha in } 1911,186,000 \text { ha in } 1938 \text { (Rédei et al. } \\
2017 \text { ) }\end{array}$ \\
\hline Ukraine & 422,525 & Lavnyy and Savchyn (2016) & \\
\hline Poland & 309,205 & Anonymous (2017a) & $\begin{array}{l}\text { Total area of stands with black locust in species composi- } \\
\text { tion (Anonymous 2017a) }\end{array}$ \\
\hline Romania & 250,000 & Enescu and Dănescu (2015) & $\begin{array}{l}\text { From } 28,000 \text { ha in 1922-100,000 ha in mid-1950 s (Enescu } \\
\text { and Dănescu 2015) }\end{array}$ \\
\hline Italy & 233,533 & Rizzo and Gasparini (2011) & \\
\hline France & $195,000 \pm 22,000$ & IGN (2018) & \\
\hline Serbia & 169,153 & Banković et al. (2009) & \\
\hline Slovenia & 157,000 & Brus et al. (2016) & \\
\hline Bulgaria & 153,851 & Executive Forest Agency (2015) & \\
\hline Croatia & 35,070 & Čavlović (2010) & \\
\hline Slovakia & 34,000 & Anonymous (2017b) & \\
\hline Germany & 34,000 & BMEL (2014) & \\
\hline Austria & $24,000-40,000$ & National Forest Inventory & \\
\hline Czech Republic & 14,087 & Vítková et al. (2016) & \\
\hline FYR Macedonia & 2622 & Mandžukovski pers.comm. & \\
\hline Belgium (Wallonne Region) & Ca. 2000 & Claessens et al. (2006) & \\
\hline Bosnia and Herzegovina & $1000-2000$ & Cvjetkovic pers.comm. & \\
\hline
\end{tabular}

areas of Germany, this species has produced 3-10 oven-dry $\mathrm{t} \mathrm{ha}^{-1} \mathrm{a}^{-1}$, substantially higher than poplar and willow clones established on the same sites (Grünewald et al. 2009). In Italy, on poplar sites, its production can reach 10 , even 12.5 dry matter $\mathrm{tha}^{-1}$ year ${ }^{-1}$ using selected clones of Hungarian provenance (Giulietti 2016). In Hungary, where black locust is considered the most suitable species for energy plantations (Rédei and Veperdi 2009), its productivity reached 9.7 dry matter $\mathrm{t} \mathrm{ha}^{-1} \mathrm{yr}^{-1}$ (Rédei et al. 2011). Black locust is also important as a raw material in the food industry, as fodder in silvopastoral systems, in biotherapy, and landscaping (Cierjacks et al. 2013; Enescu and Dănescu 2015; Ciuvăț et al. 2015; FOREST EUROPE 2015; Sitzia et al. 2016; Vítková et al. 2016). It is important in honey production (bees can collect up to $1500 \mathrm{~kg}$ of honey from one ha of black locust stands in favourable years; Vakulyuk 1991), and it provides habitat for numerous fungi, arthropods, birds and mammals (Saunier 2007; Ślusarczyk 2012; Ciuvăț et al. 2015).

In Europe, black locust is cultivated on a large scale for timber production; curiously, it is not an important 
commercial timber species in native range (Huntley 1990), where the best uses are mine timbers, fence posts, poles, railroad crossties, stakes and fuel (DeGomez and Wagner 2001). The wood is dense (specific gravity about $0.73-0.74 \mathrm{~g} \mathrm{~cm}^{-3}$ at 15\% moisture content, Erdélyi 1988; Savill 2013), even though the species is fast-growing; this combination of high wood density with high growth rate is rare among woody plant species (Hanover 1990). Black locust wood is naturally durable so can be used outdoors without any treatment. For example, it is the only broadleaved species grown in France with a natural durability specific to class 4 of the European/ French Norm NF EN 335-1 and can be used in contact with soil or freshwater and exposed permanently to humidity (Borde 2018). The uses of black locust wood in Europe include general construction, boat building, flooring/parquet, terrace floors, outdoor work, veneer, furniture, mine timbers, barrel staves, railway sleepers, vineyard poles and props, fence posts, boxes, crates, handcrafts, wood chips, pellets, particle board, fibreboard (Erdélyi 1988; Torelli 2002; Cierjacks et al. 2013; Savill 2013; Ciuvăț et al. 2015; Sitzia et al. 2016). The species produces highly-valued firewood, very important in many rural areas of Europe such as in Hungary, Serbia, Romania, Bulgaria, and Croatia. Its calorific power (97\%) is comparable to that of native oaks (pedunculate oak, Quercus robur L. and sessile oak, Q. petraea (Matt.) Liebl.), considered as $100 \%$ but lower than hornbeam (Carpinus betulus L.) (110\%) (CIRAD 2012; Bousse and Richard 2017).

The importance of this species in parts of Europe is underlined by black locust breeding and improvement programs, started in the 1950s in Germany (Schneck 2010), 1960s in Hungary (Keresztesi 1983) and Romania (Bîrlănescu et al. 1966, 1977), 1970's in Bulgaria (Kalmukov 2014), and in the 1980' in Austria (Müller 1990). These programs included initially the selection of individual trees of good stem form and vigor ('plus-trees') and of seed stands, followed by the vegetative propagation of selected 'plus-trees' and establishment of seed orchards. Using selected clones and cultivars, especially in Hungary, wood production has increased significantly, i.e., by $25-30 \%$ in Hungary (Rédei et al. 2017) and 48\% in Italy (Gras 1991). Breeding and improvement programs are undertaken in Hungary, Bulgaria, France, Greece and Poland, mainly using European provenance stock (van Loo et al. 2017). The array of breeding objectives is very wide, e.g., improvement of wood quality, increase of biomass production for energy purposes, increase of flower nectar production and extension of blossom period, and improvement of drought and frost tolerance (Gras and Mughini 2009; Kalmukov 2014; van Loo et al. 2017).

However, despite its economic and social value, the role of black locust in European forestry is controversial because of its invasiveness. It is ranked amongst the 100 most invasive alien species (“... a species that is established outside of its natural past or present distribution, whose introduction and/or spread threaten biological diversity"-Convention on Biological Diversity 1992, in https://www.iucn.org/theme /species/our-work/invasive-species) on the continent (Vilà et al. 2009). However, it is formally considered to be invasive only in a relatively low number (13 out of 35 reporting) of European countries (Brus et al. 2016). For example, German forest scientists consider black locust as "partly invasive" since its invasiveness is mostly restricted to open fields and does not occur in dense forests, with closed canopies (Vor et al. 2015). For Slovenian forest experts, black locust is an invasive species (Rudolf and Brus 2006). This emphasizes the ongoing controversy about the species: black locust has many positive socio-economic effects as shown above but can also have negative environmental effects on native vegetation as a light-demanding pioneer species that can substantially, and rather quickly, change the specific habitats which it invades (Vítková et al. 2016, 2017). Furthermore, as noted by Vítková et al. (2017), black locust has been widely accepted by the general public in central Europe, where it features in cultural and traditional artefacts.

Recent reviews [e.g., Cierjacks et al. 2013; Vitkova et al. (2017)] have described many aspects of the ecology of black locust, including ones that influence the invasiveness of the species in different parts of Europe. However, there is no comprehensive summary of the silviculture, productivity and management of black locust in Europe that can be used to inform about its future role in different countries. In this paper, along with the essential characteristics of black locust in Europe (e.g., site requirements, root system, regeneration ecology, invasive potential, shade tolerance, potential for natural pruning, vulnerability to pests and diseases), we summarize such information to outline principles for the management of this species, including stand establishment, early interventions such as release cutting and cleaningrespacing, commercial thinning and pruning (both formative and high), all with the aim of producing different wood assortments.

\section{Species characteristics}

\section{Climate}

In its native range, black locust grows in a humid climate (annual total precipitation 1020-1830 mm), with 150-210 frost-free days (Huntley 1990). In Europe, black locust behaves like a thermophilous species, i.e., it grows well where mean annual temperatures are over $8{ }^{\circ} \mathrm{C}$ (Roșu 1996; Rédei et al. 2017) and is very drought tolerant (Claessens et al. 2006; Grünewald et al. 2009; Mantovani et al. 2014; CRPF Nord Pas-de-Calais Picardie 2015). In this respect, black locust can adapt to prolonged drought by reducing water loss through both reduced transpiration and leaf size 
(Mantovani et al. 2014), as well as due to an extended root system which access water in deeper soil layers (Grünewald et al. 2009). Consequently, the species can grow in regions with 500-550 mm annual precipitation (Roșu 1996; Mantovani et al. 2014), with reports of it tolerating less than $400 \mathrm{~mm}$ year $^{-1}$ (Engel et al. 2014), high summer air temperatures of $30-35{ }^{\circ} \mathrm{C}$, and relative air humidity in July of 20-50\%, as found in Hungary (Rédei et al. 2002).

Late and early frosts, as well as low winter temperatures, are damaging for black locust both in Europe (Haralamb 1967), and in the USA (Huntley 1990). Early frosts damage un-hardened twigs and are the source of frequent forking of black locust (Haralamb 1967; Claessens et al. 2006). Storms, wet, sticky and heavy snowfall, and ice can break branches, trunks, forks or shoots at their junction with the stem (Kitin 1960; Vajda 1974; Stănescu 1979; Brus 2011; Meyer-Münzer et al. 2015). Strong winds can cause damage (breakage, uprooting) which, although very rare, can occur on forked black locust individuals (Jovanović 1967; Herman 1971; Vajda 1974; Rițiu et al. 1988).

\section{Soil and topography}

In the United States, black locust is found naturally over a wide range of soils but grows best on moist, rich, loamy soils or those of limestone origin (Huntley 1990). It thrives on moist slopes of the eastern mountains, the Appalachians, below $1040 \mathrm{~m}$ a.s.l. (Harlow et al. 1986), while in the Great Smoky Mountains National Park, its upper elevational limit is $1620 \mathrm{~m}$ a.s.l. (Whittaker 1956 in Huntley 1990).

In Europe, the species has been introduced over a wide range of soils and tolerates diverse $\mathrm{pH}$ from extremely acid (3.2) to alkaline (8.8) (Vítková et al. 2015). However, it grows best when the soil $\mathrm{pH}$ is slightly acid to near neutral, 5.5-7.0 (Roșu 1996; Borde 2011; Zajączkowski and Wojda 2012). Black locust tolerates dry and nutrient poor soils, but grows best on deep, nutrient-rich, moist, uncompacted, well-drained silt loams, sandy loams, or sandy soils (Haralamb 1967; Rédei et al. 2011; Meyer-Münzer et al. 2015). Under these conditions, the root-associated nitrogen fixing Rhizobium bacteria, which fixes up to $75 \mathrm{~kg}$ of $\mathrm{N} \mathrm{ha}^{-1}$ year $^{-1}$ (Boring and Swank 1984) or $150 \mathrm{~kg}$ of $\mathrm{N} \mathrm{ha}^{-1}$ year $^{-1}$ (Berthold et al. 2005), are able to thrive. The groundwater table should be deeper than $150 \mathrm{~cm}$ (Keresztesi 1988a, b; Zajączkowski and Wojda 2012), as nitrogen fixation aerobic Rhizobium bacteria is inhibited by high water table or periods of flooding (Vítková et al. 2015). Rendzinas, calcium-carbonated soils in the upper horizons, poorlydrained and highly compacted (clayey) soils, very dry as well as hydromorphic soils with gley or pseudogley, are not suitable for black locust (Stoyanov 1926; Donchev 1968;
Rameau et al. 1989; Claessens et al. 2006; Borde 2011; Boer 2013).

In Europe, black locust has been used across a wide range of altitudes, from sea level to $1640 \mathrm{~m}$ a.s.l. in the Southern Alps of Italy (Sitzia et al. 2016), but grows best in plains and hilly areas at altitudes below 600-700 m a.s.l. (Vuković et al. 2013; Šnjegota et al. 2017).

\section{Root system}

The root system of black locust is dimorphic, heart-shaped: when young, it develops a tap root which is supplemented by further vertical roots extending down to 40-60 cm (Spîrchez et al. 1962; Benčat pers.comm.), and horizontal ones spreading radially as far as $20-30 \mathrm{~m}(1.0-1.5$ tree heights) (Wraber 1951; Negulescu and Săvulescu 1957; Cutler 1978, in Huntley 1990; Stănescu 1979).

However, the root architecture (depth and width) depends on soil conditions: on deep, loose and moist soils as well as dry sandy soils, the roots are well developed, densely branched, with a taproot/vertical roots $1.5-3 \mathrm{~m}$ depth (a maximum $7.9 \mathrm{~m}$ in Europe, Schütt 1994; a maximum 6-7.5 $\mathrm{m}$ in native range, Harlow et al. 1986). On shallow soils or eroded slopes, there is no taproot but fine flat, widespread horizontal roots close to the soil surface with an umbrella-like shape. As acknowledged by Huntley (1990), the species deep rooting ability may explain why can grow in regions much drier than its native range such as in Hungary, Romania, Bulgaria, and China.

\section{Regeneration ecology}

Both in native range (McAlister 1971; Huntley 1990) and in Europe (Stoyanov 1926; Negulescu and Săvulescu 1957; Haralamb 1967; CRPF 2007; Branquart et al. 2007; Rédei et al. 2008; Vuković et al. 2013) as well as in Asia (Luna 1996), natural regeneration is primarily by root suckers. These are produced abundantly even by trees over 70 years old (Vítková et al. 2017) from superficial roots, particularly following mechanical damage to the root system (Boer 2013; Vítková et al. 2016) or soil disturbance (Savill 2013). The number of suckers per tree can range from 1-2 up to 45-46 (Dimitrov 2001), so initial stocking after one growing season reach 40,000-60,000 suckers ha ${ }^{-1}$ (Pagès 1985, cited by Carbonnière et al. 2007; Nicolescu et al. 2019). More suckers are produced in open, sunny areas, and on sandy loam than in shade, dense vegetation or on heavy soils (Converse 1984; Wieseler 2005, cited by Boer 2013; Stone 2009).

Black locust also regenerates on a much smaller scale by stool shoots arising from dormant buds on the stump crown (the callus zone), or on the lower portion of the trunk; sprouting is intensive and persistent (Brus 2011; Boer 2013). 
However, root suckers live longer and are healthier, showing less rot at the same age than stool shoots (Negulescu and Săvulescu 1957; Stănescu 1979).

Black locust produces abundant seed crops with $120-150 \mathrm{~kg}$ of seeds $\mathrm{ha}^{-1}$ in an average seed year, beginning from around 6 years of age (Rédei et al. 2001; Rédei 2013a, b, c, d). Good seed crops occur every 1-2 years in both Europe (Haralamb 1967; Rédei et al. 2012; Boer 2013; Los et al. 2014; Meyer-Münzer et al. 2015) and the USA (Huntley 1990). The seeds are light (20-23 g for 1000 seeds) and long-lived, mostly gravity- and wind-dispersed in the vicinity of the parent tree. Long-distance spread of seeds by natural means is not very common (Boer 2013; Vítková et al. 2017); however, they have been found up to $67 \mathrm{~m}$ away from the parent tree (Morimoto et al. 2010, cited by van Loo et al. 2017). They may persist in a dormant state in the soil for a long time, with a viability longer than 10 years (Haralamb 1967; Boer 2013) or, in some circumstances, up to 40 years (Toole and Brown 1946, cited by Cseresnyés and Csontos 2012), accumulating in a permanent seed bank (Stone 2009; Filipas 2013). This should be taken into consideration when devising strategies to eradicate unwanted black locust (Boer 2013). However, because the heavy, thick seed coat is impermeable to water (both absorption and loss), germination is restricted (McAlister 1971; Vlase 1982; Branquart et al. 2007) so regeneration from seed is rare (Tănăsescu 1961, 1967; Boer 2013). Germination rate is low under natural conditions (Branquart et al. 2007), ranging from $3.5 \%$ to $16.3 \%$ (Roberts and Carpenter 1983) to 22\% (Singh et al. 1999, both cited by Cierjacks et al. 2013). However, natural regeneration from seed can be facilitated by seed wounding with heavy machinery (Tănăsescu 1961) or by natural thermal shock. The latter occurs particularly on sand dunes where temperatures of the surface layer reach $60-65^{\circ} \mathrm{C}$ in summer (Spîrchez et al. 1962).

\section{Invasive potential}

As a N-fixing species, black locust creates irreversible changes in physico-chemical and biological soil properties. It influences the species composition of ground flora under its canopy by favouring ruderal and species-poor neutrophilous weed associations, eliminating oligotrophic and acidophilous ones typical of forests, thereby reducing plant diversity (Kleinbauer et al. 2010; Benesperi et al. 2012; Cseresnyés and Csontos 2012; Dimitrova 2012; Vuković et al. 2013). In invaded stands, as soil $\mathrm{pH}$ is significantly lower and soil $\mathrm{NO}_{3}{ }^{-}$significantly higher, soil microarthropode communities suffer significant loss of abundance and richness while nematode taxon richness is significantly lower (Lazzaro et al. 2018).

Black locust also produces different allelopathic compounds (e.g., robinetin, myricetin and quercetin) which may affect the ecological functioning of natural areas by inhibiting the growth of various weeds and crop species (Nasir et al. 2005; Boer 2013). However, as the allelopathic effects of black locust have not yet been tested under natural conditions, it seems that vegetation change towards ruderal and nitrophilous species is caused by the change in the availability of soil nutrients rather than by allelopathy (Vítková and Kolbek 2010).

Once introduced in an area, black locusts expands readily into open sites where they form dense colonies and their shade reduces competition from other sun-loving species hindering their natural regeneration and thus a local, small-scale reduction of biodiversity can occur (Kutnar and Kobler 2013).

However, black locust has also some positive effects on biodiversity (Vítková et al. 2016, 2017): (a) Provides habitat for some rare and endangered plant species (e.g., rare ruderal plants). (b) In species-poor agricultural landscapes, black locust stands can increase diversity and play a significant role as migration corridors for woodland animals. (c) The dense undergrowth of shrubs and complex canopy structure provide nesting opportunities and a food source for many bird species. Among the birds are habitat generalists rather than specialist species, and their total number can be higher in the stands invaded by black locust than in, for example, oak stands. (d) Old black locust individuals can provide a refuge for saprophagous beetles, including rare species.

In Central Europe, habitats most often invaded by black locust are confined to low and medium altitudes (Kleinbauer et al. 2010; Boer 2013; Crosti et al. 2016; Vítková et al. 2016, 2017; Lazzaro et al. 2018; https://invasoras.pt/en/galle ry/robinia-pseudoacacia-en) and include: (1) Dry and semiarid grasslands, including those on open sandy steppes and rocky outcrops. (2) Dry (including nutrient-poor oak-dominated) forests and shrubland. (3) Alluvial habitats (banks of watercourses) but only on well-drained sites, sandy, gravelsandy and gravel banks on flood barriers experiencing only occasional short-term flooding. (4) Agrarian landscapes with abandoned fields, orchards, vineyards, hedgerows, gullies, windbreaks, and roadsides. (5) Urban and industrial environments including toxic man-made substrates (e.g., polluted or salty soils). (6) Disturbed sites in most habitats, e.g., post-fire sites, windthrows, previously flooded areas, forest clearings, degraded forestry plantations.

In native range, black locust is considered an invasive in the prairie and savanna regions of the American Midwest where it can dominate and shade these open habitats (Swearingen and Bargeron 2016).

The invasion by root suckers occurs only around areas where it is already established, i.e., invasiveness is limited and the threats that the species could pose to biodiversity are localized. As mentioned, black locust does not occur in 
dense forests or shrublands, with closed canopies: as seedlings are intolerant of shade, mortality is high in closed forests (Boring and Swank 1984; Kowarik 2011; Boer 2013; Crosti et al. 2016; Vítková et al. 2016, 2017). In such stands, it can only occur as individual trees or groups of trees after disturbance results in a gap in the canopy (e.g., after trees die, fire, windthrow or forest management) where there is less competition (Cierjacks et al. 2013; Vítková et al. 2017).

In general, habitats that are resistant to black locust invasion (Crosti et al. 2016; Vítková et al. 2016) include: (1) areas with compacted and poorly aerated soils such as gleysols in alluvial forests subject to frequent and long-term waterlogging; (2) intensively managed sites where the vegetation is permanently disturbed (e.g., trampled sites, mown lawns and meadows or arable fields); (3) dense forests of competitive shade-tolerant species such as European beech (Fagus sylvatica L.); and (4) mountain and subalpine areas with frosts, short growing seasons and cold climate. These are the reasons why black locust is sometimes considered only a "partly invasive" species as proposed by German forest experts (Vor et al. 2015).

Interestingly, agricultural landowners consider black locust as invasive only when it spreads onto agricultural lands; they appreciate and manage black locust stands on poor and dry sites (e.g., sand dunes, south-facing slopes, with shallow soils), where it performs better than other native tree species (Kutnar and Kobler 2013; Stančič 2015).

The current range of black locust in Europe is under strong temperature constraints, and it is projected to expand in response to climate change (Boer 2013; Kutnar and Kobler 2013; Giuliani et al. 2015; Dyderski et al. 2017), so the species is expected to invade new sites and also increase its population in already occupied areas (Kleinbauer et al. 2010). It is the case of managed temperate forests of Europe, currently dominated by European beech and Norway spruce (Picea abies (L.) Karst), where species like black locust, northern red oak (Quercus rubra L.), Turkey oak (Quercus cerris L.) and fluttering elm (Ulmus laevis Pall.) are considered as interesting alternatives if the predicted northward shift of $461 \mathrm{~km}$ and $697 \mathrm{~km}$ for thermophilic species under warming scenarios of $2.9^{\circ} \mathrm{C}$ and $4.5^{\circ} \mathrm{C}$, respectively, over the 2060-2080 period is realized (Thurm et al. 2018).

Under climate changes, preventive and control measures are needed and should include: (1) Establishment of a managed buffer zone around black locust plantations to act as a biological barrier for the species (Crosti et al. 2016); (2) Planning its introduction close to and within areas of ecological and environmental value (e.g., Natura 2000 sites) as well as in rare or threatened forest habitats (Borde 2011; Crosti et al. 2016); (3) Conversion from coppice to high forests by cessation of coppice cuts combined with lengthening rotation age and use of an alternative cutting system (Radtke et al. 2013; Nadal-Sala et al. 2019; La Porta pers.comm.); (4)
Application of mechanical, chemical or biological control measures to eradicate or reduce the presence of black locust.

The detailed application of these preventive and control measures will be presented in the 'Management of black locust' section of this article.

However, we fully agree with Vítková et al. (2016, 2017) and Sádlo et al. (2017) that a stratified and sitespecific management approach, tolerating (or even favouring) black locust in selected areas and strictly eradicating it from naturally valuable habitats, is the only solution for a strict and rational management of the species in Europe. This approach should take into account both the ecological and economic aspects associated with the occurrence of black locust in different types of Robinia habitats.

\section{Shade tolerance}

In both the native range (Trimble 1975, cited by Huntley 1990; DeGomez and Wagner 2001) and in Europe (Poskin 1926; Negulescu and Săvulescu 1957; Haralamb 1967; Herman 1971; CRPF 2007; Brus 2011; Vuković et al. 2013), black locust is considered a strong lightdemanding tree species, intolerant of shade (growing best in full sun) and competition; therefore it is found in closed stands only as a dominant tree (McAlister 1971; Huntley 1990), requiring spacing at crown level for optimal growth (Poskin 1926). Black locust grown on poor sites cannot withstand shade so self-thinning is very high under such conditions (Herman 1971). Lyr et al. (1963) found a lower shade tolerance of black locust compared to Q. rubra, Pseudotsuga menziesii (Mirbel.) Franco, Pinus sylvestris L., Betula pendula Roth, Alnus glutinosa (L.) Gaertn. in terms of lower relative growth rates under shade and higher shoot/root ratios under increasing shade. As with other light-demanding tree species (e.g., Populus nigra L., Fraxinus pennsylvanica Marsh.), mature black locust trees show a pronounced phototropism and develop a leaning stem (a deformity reducing the milling potential) in search for light (Evans 1984; MAPPM 2000b).

\section{Potential for natural pruning}

Black locust, as a strong light-demanding tree species, shows a good potential for natural pruning but when trees are grown in abundant light, they do not self prune and tend to develop large and deep crowns (Rédei 2013b). Kalmukov (1995) showed the influence of six different planting spacings $(1.5 \times 0.5 \mathrm{~m}, 1.5 \times 1.0 \mathrm{~m}, 1.5 \times 1.5 \mathrm{~m}, 2 \times 0.5 \mathrm{~m}, 2 \times 1 \mathrm{~m}$, and $2 \times 1.5 \mathrm{~m}$ ) on natural pruning of black locust: at age seven, the branch-free part of the bole ranged from $1.5 \mathrm{~m}$ in the widest planting scheme to $2.8 \mathrm{~m}$ in the closest one. 
However, even when grown in dense stands, it is not a perfect self-pruner so the removal of low branches is necessary to produce 1st grade sawlogs designated for top-quality wood products such as veneer (Haralamb 1967; Rédei 2013b; Meyer-Münzer et al. 2015).

\section{Vulnerability to pests, diseases and wildlife}

In Europe, black locust appears to have high pest and disease resistance; however, in recent decades, several insects, fungi and semi-parasites have been reported to affect mature trees, seeds and seedlings. For instance, the leaves have been affected by black locust leaf miner (Phyllonorycter robiniae Clemens), locust digitate leaf miner (Parectopa robiniella Clemens), black locust gall midge (Obolodiplosis robiniae Hald.), gall midge (Platygaster robiniae n.sp.), soft scale (Parthenolecanium corni Bouché), and black bean aphid (Aphis fabae Scopoli). In countries like Bosnia and Herzegovina, Bulgaria, Croatia, Germany, Hungary, Italy, Romania, Poland, these have caused reduced leaf assimilation, loss of the aesthetic attributes of leaves, reduced value for honey production and, in extreme cases, premature leaf drop/ defoliation (Trenchev et al. 1993; Maceljski and Mešić 2001; Tomov 2003; Duso et al. 2005; Mihajlović and Stanivuković 2009; Pernek and Matoševic 2009; Branco et al. 2016; Olenici and Duduman 2016; Šiljeg 2017).

Black locust seeds have been affected in Bulgaria, Romania and Slovakia by insects such as locust sawfly, Eurytoma caraganae Nikolskaya being the most common, as well as lima bean pod borer Etiella zinckenella $\mathrm{Tr}$. and locust seed beetle Kitorrhinus quadriplagiatus Mots., the proportion of damaged seeds reaching ca. 80\% (Iliev et al. 2005).

Black locust is considered a species very resistant to wood decay caused by fungi (Glavaš 1999). However, some fungi genera such as Fusarium, Polyporus, Perenniporia, Ganoderma, Laetiporus, and Fomes have caused white, brown or red rot, especially after stems or roots have been damaged (Schütt 1994; Tomiczek et al. 2008; Meyer-Münzer et al. 2015). Black locust roots are also affected by Armillaria spp., causing root decay especially if the trees are stressed by drought (Aslam 2015).

The semi-parasitic mistletoes, Viscum album L. and Loranthus europaeus Jacq. are sporadically found on black locust (Idžojtic 2003; Idžojtic et al. 2006).

Fortunately, the most important pest in native range, the locust borer Megacyllene robiniae (Forst.), is not yet present in Europe. Tunnels produced by its larvae in the heartwood weaken tree limbs, making them susceptible to breakage by wind and also serve as primary infection sites for windborne spores of the fungus Phellinus rimosus (Berk.) Pilát which causes damaging heart rot disease. This combined attack makes growing black locust for timber production impractical where this pest is present (Huntley 1990).
In countries like Bulgaria, Germany, Hungary, Slovakia, Austria and Romania, the European hare (Lepus europaeus Pallas) and European rabbit (Oryctolagus cuniculus L.) peel-off the bark of young trees (in nurseries and in forest stands), while red deer (Cervus elaphus L.) and roe deer (Capreolus capreolus L.) browse the young shoots, leaves and buds, causing significant damage (Juhásová and Hrubík 1984; Trenchev et al. 1993; Iby 1997; Claessens et al. 2006; Rédei et al. 2012). Similarly, in the USA, white-tailed deer (Odocoileus virginianus Zimmerman) is a major problem for young black locust, with reports of up to $92 \%$ of shoots browsed in the southern Appalachians (Della-Bianca and Johnson 1965, cited by Huntley 1990).

\section{Growth and yield dynamics}

\section{Height growth}

In both the native range (Harlow et al. 1986) and in Europe (France, Merzeau et al. 2008; Hungary, Rédei 2013b; Poland, Zajączkowski and Wojda 2012; Romania, Haralamb 1967; Germany, Meyer-Münzer et al. 2015; Carl 2018), black locust grows rapidly in height for the first $10-15$ years. Consequently, the trees can reach heights of $10 \mathrm{~m}$ at 5 years and $14 \mathrm{~m}$ at 10 years on the best sites (Rédei 1984; Ruhm 2013). The peak growth rate in height occurs on the best sites with warm climate, rich and deep soils within the first decade: in the first 5 years (France, Merzeau et al. 2008; Germany, Lockow and Lockow 2015; Hungary, Rédei 1984; Poland, Zajączkowski and Wojda 2012) or in the first 10 years (Austria, Ruhm 2013; Ukraine, Lavnyy pers. comm.; Romania, Negulescu and Săvulescu 1957). The better the site potential, the earlier the peak of height growth. This slows after 15 years (Haralamb 1967), although growth remains relatively rapid in older trees; black locust stands in Europe can reach mean or dominant heights of over $20 \mathrm{~m}$ at 20 years and up to $25-30 \mathrm{~m}$ at 30 years (Tables 3,4 ).

Stool shoots grow more rapidly in height (maximum $4.9 \mathrm{~m} \mathrm{year}^{-1}$ in Germany, Lockow and Lockow 2015) than either root suckers (up to 2-3 $\mathrm{m} \mathrm{a}^{-1}$, Lockow and Lockow 2015) or planted seedlings up to 15-20 years of age (Haralamb 1967; Stănescu 1979; Stănescu et al. 1997). This trend in height growth rate reverses later, with the height of seed-originating stands outstripping that of coppice stands of the same age (Haralamb 1967; Negulescu and Săvulescu 1957; Stănescu 1979) (Tables 3, 4).

Currently, the tallest trees in Europe are found in France (38 m, IGN 2018) and Germany (39 m, Lockow and Lockow 2015). 
Table 3 Maximum and minimum mean height at different ages in pure black locust stands in different European countries

\begin{tabular}{|c|c|c|c|c|c|c|c|c|c|c|}
\hline \multirow[t]{3}{*}{ Country } & \multicolumn{8}{|c|}{ Mean height at... years (m) } & \multirow[t]{3}{*}{ Source } & \multirow[t]{3}{*}{ Notes } \\
\hline & \multicolumn{2}{|l|}{10} & \multicolumn{2}{|l|}{20} & \multicolumn{2}{|l|}{25} & \multicolumn{2}{|l|}{30} & & \\
\hline & Min & Max & Min & Max & Min & Max & Min & $\operatorname{Max}$ & & \\
\hline Hungary & 6.5 & 13.6 & 10.2 & 21.5 & 11.3 & 23.8 & 12.1 & 25.4 & Rédei et al. (2014) & \\
\hline Romania & 5.0 & 14.7 & 8.7 & 23.4 & 10.3 & 26.6 & 11.7 & 29.5 & Giurgiu and Drăghiciu (2004) & Plantation \\
\hline Romania & 5.5 & 15.8 & 8.8 & 22.8 & 10.1 & 25.1 & 11.2 & 27.2 & Giurgiu and Drăghiciu (2004) & Coppice \\
\hline Bulgaria & 5.8 & 13.0 & 10.2 & 19.8 & 11.5 & 21.5 & & & Poryazov et al. (2004) & Plantation \\
\hline Bulgaria & 5.0 & 14.2 & 7.4 & 19.6 & & & & & Poryazov et al. (2004) & Coppice \\
\hline Croatia & 9.0 & 13.0 & 14.0 & 19.0 & 15.5 & 20.5 & 17.0 & 22.0 & Đodan pers.comm. & \\
\hline Germany & 6.3 & 12.3 & 10.8 & 18.8 & 12.4 & 21.1 & 13.7 & 23.0 & Lockow and Lockow (2015) & \\
\hline
\end{tabular}

Min, minimum; Max, maximum

Table 4 Maximum and minimum dominant heights at different ages in pure black locust stands in different European countries

\begin{tabular}{|c|c|c|c|c|c|c|c|c|c|c|}
\hline \multirow[t]{3}{*}{ Country } & \multicolumn{8}{|c|}{ Dominant height $(\mathrm{m})$ at. years } & \multirow[t]{3}{*}{ Source } & \multirow[t]{3}{*}{ Obs. } \\
\hline & \multicolumn{2}{|l|}{10} & \multicolumn{2}{|l|}{20} & \multicolumn{2}{|l|}{25} & \multicolumn{2}{|l|}{30} & & \\
\hline & Min & Max & Min & Max & Min & Max & Min & Max & & \\
\hline Romania & 6.7 & 17.6 & 11.1 & 26.5 & 12.8 & 29.6 & 14.4 & 32.4 & Giurgiu and Drăghiciu (2004) & Plantation \\
\hline Romania & 7.2 & 18.8 & 11.2 & 25.8 & 12.7 & 28.2 & 13.9 & 30.1 & Giurgiu and Drăghiciu (2004) & Coppice \\
\hline Belgium (Wallonne Region) & 6.4 & 12.2 & 10.6 & 20.1 & 12.2 & 22.9 & 13.8 & 25.7 & Claessens et al. (2006) & \\
\hline France (Aquitaine Region) & 9.0 & 17.5 & 14.0 & 25.2 & 16.0 & 27.8 & 17.5 & 29.8 & Merzeau et al. (2008) & \\
\hline
\end{tabular}

Min, minimum; Max, maximum

\section{Diameter growth}

Black locust trees have rapid early diameter growth that can reach 3-4 cm in the first year (stool shoots and root suckers, Jovanović 1967) on the best sites. The diameter increment peaks early on such sites: before age 10 (at 5 years in Germany, Lockow and Lockow 2015; 6-8 years in Poland, Węgorek and Kraszkiewicz 2005; Klisz et al. 2014; 7 years in Slovenia, Kadunc 2016), at the end of the first decade (Austria, Ruhm 2013; Bulgaria, Dimitrov 2001; Hungary, Rédei 1984; Rédei et al. 2008; France, Merzeau et al. 2008) or between 12 and 20 years (Romania, Negulescu and Săvulescu 1957; Belgium, Claessens et al. 2006; Slovenia, Kadunc 2016). The better the site potential, the earlier the peak of diameter growth (e.g., from 7 years on the best sites to 18 years on the poorest in Slovenia, Kadunc 2016).

In France, black locust trees grow $1 \mathrm{~cm} \mathrm{a}^{-1}$ on average (range 0.5-1.9 $\mathrm{cm} \mathrm{a}^{-1}$, Merzeau et al. 2008; CRPF Nord Pasde-Calais Picardie 2015). Savill (2013) mentions diameter increments of $0.2-2.0 \mathrm{~cm}$, the maximum being similar to the one from German production tables $\left(1.8 \mathrm{~cm} \mathrm{a}^{-1}\right.$, Lockow and Lockow 2015).

As in the case of height, stool shoots have larger diameters than root suckers and planted seedlings up to 15-20 years of age. The trend in diameter growth rate reverses later with the diameter of seed-originating stands exceeding that of coppice stands of the same age (Haralamb 1967).

In the best growing conditions in native range and in Europe, $20 \mathrm{~cm}$ diameter trees take 25-30 years to be produced (Roach 1965, in Huntley 1990; Giurgiu and Drăghiciu 2004; Kalmukov 2014; Rédei et al. 2014). Trees $50 \mathrm{~cm}$ in diameter can be produced before 60 years of age (Claessens et al. 2006; Dancart 2019).

Large diameter black locust trees are found in Europe in Germany (244 cm in diameter-https://www.ddg-web.de/ index.php/rekordbaeume.html), Belgium (208 cm), Great Britain $(198 \mathrm{~cm})$, Austria $(172 \mathrm{~cm})$, Hungary $(170 \mathrm{~cm})$, Romania $(169 \mathrm{~cm})$, Slovakia $(161 \mathrm{~cm})$, Poland $(156 \mathrm{~cm})$, Netherlands $(156 \mathrm{~cm})$ (all from https://www.monumental trees.com/en/trees/blacklocust/records), and Italy $(140 \mathrm{~cm}$, MIPAAF 2017). These large diameters are produced by old trees, 415 years of age in France, 340 years (Netherlands), 290 years (Germany), 240 years (Poland), 260 years (Great Britain), 210 years (Italy) (all from https://www.monumental trees.com/en/trees/blacklocust/records).

\section{Volume growth and yield}

Black locust quickly increases in volume while young, reaching maximum mean annual volume increment of 
10-12 $\mathrm{m}^{3} \mathrm{ha}^{-1} \mathrm{a}^{-1}$ in Germany and Bulgaria or $14-16 \mathrm{~m}^{3}$ $\mathrm{ha}^{-1} \mathrm{a}^{-1}$ in Romania as early as 5-10 years (coppice stands) and 15-22 years (plantations), depending on the productivity class (Table 5).

These values are similar to those achieved in native range (up to $14 \mathrm{~m}^{3} \mathrm{ha}^{-1} \mathrm{a}^{-1}$ on the best sites; Hanover 1990). In other countries black locust grows $2.5-11.5 \mathrm{~m}^{3} \mathrm{ha}^{-1} \mathrm{a}^{-1}$ (Ukraine, Lavnyy pers.comm.), 3.1-7.4 $\mathrm{t} \mathrm{ha}^{-1} \mathrm{a}^{-1}$ (Slovakia, Benčat 1989), 4-14 $\mathrm{m}^{3} \mathrm{ha}^{-1} \mathrm{a}^{-1}$ (Belgium, Claessens et al. 2006), 4.5-12 $\mathrm{m}^{3} \mathrm{ha}^{-1} \mathrm{a}^{-1}$ (Croatia, Đodan pers. comm.), 6-10 $\mathrm{m}^{3} \mathrm{ha}^{-1} \mathrm{a}^{-1}$ (Netherlands, Mohren pers.comm.), $7.5 \mathrm{~m}^{3}$ $\mathrm{ha}^{-1} \mathrm{a}^{-1}$ (over 60 years; Germany, Lockow 2005), $7.7 \mathrm{~m}^{3}$ $\mathrm{ha}^{-1} \mathrm{a}^{-1}$ (France, Borde 2011), 8-14 $\mathrm{m}^{3} \mathrm{ha}^{-1} \mathrm{a}^{-1}$ (Belgium, Dancart 2019), and $9.5 \mathrm{~m}^{3} \mathrm{ha}^{-1} \mathrm{a}^{-1}$ (over 78 years; Poland, Feliksik et al. 2007).

As black locust grows rapidly in the first decades, wood production can reach important levels quite early: over $200 \mathrm{~m}^{3} \mathrm{ha}^{-1}$ at 20 years, $290 \mathrm{~m}^{3} \mathrm{ha}^{-1}$ at 30 years and $350 \mathrm{~m}^{3}$ $\mathrm{ha}^{-1}$ at 40 years in the best site conditions (Table 6).

However, these data do not reveal the relationship between productivity and method of reproduction; for both stool shoots and root suckers, wood production decreases significantly over time (particularly in the case of stool shoots), from the first to the third generation (Table 7).

Table 5 Mean volume growth of pure black locust stands in different European countries

\begin{tabular}{|c|c|c|c|c|c|c|c|c|c|c|c|c|c|}
\hline \multirow[t]{3}{*}{ Country } & \multicolumn{10}{|c|}{ Mean volume growth of main crop at... years $\left(\mathrm{m}^{3} \mathrm{ha}^{-1}\right.$ year $\left.^{-1}\right)$} & \multirow{3}{*}{$\begin{array}{l}\text { Age of maximum } \\
\text { volume growth } \\
\text { (year) }\end{array}$} & \multirow[t]{3}{*}{ Source } & \multirow[t]{3}{*}{ Notes } \\
\hline & \multicolumn{2}{|l|}{10} & \multicolumn{2}{|l|}{20} & \multicolumn{2}{|l|}{25} & \multicolumn{2}{|l|}{30} & \multicolumn{2}{|l|}{40} & & & \\
\hline & Min & $\operatorname{Max}$ & Min & Max & Min & Max & Min & Max & Min & Max & & & \\
\hline Bulgaria & 2.9 & 11.0 & 3.7 & 11.6 & 3.6 & 10.6 & & & & & $15-20$ & Poryazov et al. (2004) & Plantation \\
\hline Bulgaria & 2.1 & 11.2 & 2.0 & 10.3 & & & & & & & $5-10$ & Poryazov et al. (2004) & Coppice \\
\hline Germany & 2.7 & 10.0 & 3.7 & 10.5 & 3.8 & 10.2 & 3.8 & 9.7 & 3.8 & 8.9 & $15-20(25)$ & Lockow and Lockow (2015) & \\
\hline Hungary & 2.7 & 8.4 & 2.9 & 9.7 & 2.8 & 9.6 & 2.7 & 9.3 & 2.5 & 8.5 & 20 & Rédei et al. (2014) & \\
\hline Romania & 2.6 & 14.1 & 2.9 & 15.8 & 3.0 & 15.4 & 3.1 & 14.9 & 3.3 & 13.7 & $18-22(24)$ & Giurgiu and Drăghiciu (2004) & Plantation \\
\hline Romania & 2.8 & 14.5 & 2.8 & 13.6 & 2.7 & 12.8 & 2.7 & 12.2 & 2.6 & 10.8 & 10 & Giurgiu and Drăghiciu (2004) & Coppice \\
\hline
\end{tabular}

Min, minimum; Max, maximum

Table 6 Yield of pure black locust stands at different ages in some European countries

\begin{tabular}{|c|c|c|c|c|c|c|c|c|c|c|c|}
\hline \multirow[t]{3}{*}{ Country } & \multicolumn{10}{|c|}{ Yield of black locust stands at.years $\left(\mathrm{m}^{3} \mathrm{ha}^{-1}\right)$} & \multirow[t]{3}{*}{ Source } \\
\hline & \multicolumn{2}{|l|}{10} & \multicolumn{2}{|l|}{20} & \multicolumn{2}{|l|}{25} & \multicolumn{2}{|l|}{30} & \multicolumn{2}{|l|}{40} & \\
\hline & Min & Max & Min & Max & Min & Max & Min & Max & Min & Max & \\
\hline Bulgaria (plantation) & 51 & 177 & 73 & 231 & 90 & 264 & & & & & Poryazov et al. (2004) \\
\hline Bulgaria (coppice) & 31 & 163 & 40 & 206 & & & & & & & Poryazov et al. (2004) \\
\hline Germany & 50 & 159 & 74 & 210 & 96 & 254 & 115 & 292 & 150 & 354 & Lockow and Lockow (2015) \\
\hline Hungary & 43 & 141 & 58 & 194 & 71 & 241 & 82 & 280 & 98 & 341 & Rédei et al. (2014) \\
\hline Ukraine & $108^{\mathrm{a}} / 129^{\mathrm{b}}$ & & $156^{\mathrm{a}} / 177^{\mathrm{b}}$ & & $198 / 219$ & & $233^{\mathrm{a}}$ & & $277^{\mathrm{a}}$ & & Anonymous (1987) \\
\hline Romania (plantation) & 40 & 233 & 57 & 316 & 74 & 385 & 94 & 447 & 133 & 549 & Giurgiu and Drăghiciu (2004) \\
\hline Romania (coppice) & 28 & 145 & 56 & 272 & 69 & 322 & 81 & 365 & 105 & 433 & Giurgiu and Drăghiciu (2004) \\
\hline
\end{tabular}

Min, minimum; Max, maximum

Ukraine: ${ }^{a}$ best site type, plantation; ${ }^{b}$ good site type, coppice

Table 7 Evolution of total wood production in stands regenerated by planting, stool shoots and root suckers, depending on the generation (Bîrlănescu and Costea 1962)

\begin{tabular}{|c|c|c|c|c|c|c|}
\hline \multicolumn{7}{|c|}{ Total wood production (\%) } \\
\hline \multirow[t]{2}{*}{ Plantations } & \multicolumn{3}{|l|}{ Stool shoots } & \multicolumn{3}{|l|}{ Root suckers } \\
\hline & 1st generation & 2nd generation & 3rd generation & 1st generation & 2nd generation & 3rd generation \\
\hline 100 & 86 & 70 & 40 & 89 & 89 & 89 \\
\hline
\end{tabular}




\section{Management of black locust}

\section{Goals}

The goals of managing black locust depend on the location of the stand (e.g., areas of high ecological and environmental values versus stands under regular forest management) and the function (e.g., protection/conservation vs. wood or biomass production) (Sádlo et al. 2017).

In areas with high ecological and environmental values, such as Natura 2000 sites, or with rare or threatened forest habitats, the goal (e.g., Germany, Poland, Slovakia, Ukraine, Vor pers.comm.; Klisz pers.comm.; Benčå pers. comm.; Lavnyy pers.comm.) is to strictly eradicate existing black locust from species compositions and return to native species (Vítková et al. 2016). To avoid further invasion of black locust into as yet un-colonized spaces within protected areas, the prevention of introducing the species by deliberate planting, based on legal restrictions, is the target (Kleinbauer et al. 2010; Boer 2013).

\section{Management of black locust in areas with high conservation values}

In such areas, the main goal is strict eradication and replacement with native species. The most important eradication techniques for black locust control are manual, mechanical, chemical, mechanical/chemical and biological.

Manual control consisting of hand pulling is preferred for seedlings and small saplings and should guarantee that no roots are left in the ground (Boer 2013; https://invasoras.pt/ en/gallery/robinia-pseudoacacia-en).

The mechanical control of black locust includes low cutting and girdling of trees (Sabo 2000; Boer 2013). The most efficient method is incomplete girdling which includes the removal of a strip of bark and sapwood $8 \mathrm{~cm}$ wide from 9/10ths of the girth, followed by complete girdling in the following growing season and later low cutting. The tree does not produce further root suckers and stool shoots (Starfinger and Kowarik 2003). However, the efficiency of both low cutting and girdling is debated (Boer 2013) since killing the main stem is often followed by formation of shoots from the tree base (Sabo 2000).

Chemical control includes foliar spraying (late in the growing season) and tree injection (after making incisions into the sapwood). Active chemical substances to be used are glyphosate, triclopyr, picloram, each diluted with water, as well as an atrazine-simazine mixture (Boer 2013; invasoras. pt/en/gallery/robinia-pseudoacacia-en).

The combination of mechanical and chemical control involves (1) cutting or girdling the trees; (2) applying herbicide on the stump or the girdled area of the trunk (Vítková 2011; Vítková et al. 2016; https://invasoras.pt/en/gallery/ robinia-pseudoacacia-en). The chemical substances are as above (most cited: glyphosate) (Sabo 2000; https://invasoras . pt/en/gallery/robinia-pseudoacacia-en).

Biological control makes use of domestic goats and cattle which defoliate black locust; in the native range after 4 years of browsing, all trees had been killed (Stone 2009).

As complete eradication of black locust is not possible since such treatment is expensive because of continuous stump sprouting, one way to fulfill the objective of replacing the species is prolonging the rotation age until the trees become senescent and are replaced naturally by native species (Motta et al. 2009). Prevention measures, like avoidance of disturbances (e.g., soil disruption) that favor black locust colonization/dispersal by root suckers, are also possible (Boer 2013).

\section{Management in areas with wood production objectives}

The rotation length is shortest when black locust is grown for biomass energy production: 3-5 years in very short rotation coppice (Borde 2011; Rédei 2013a, b, c, d; Steinegger and Reh 2013), and is 5-7 years in Italy (Facciotto et al. 2008) or 10 years in France (Bousse and Richard 2017) in short rotation coppice.

In black locust stands for wood production, the rotation age depends on:

1. Type of wood product: rotation age is 50-60 (even 70) years when sawlog $(\mathrm{dbh}>40 \mathrm{~cm})$ production is targeted as in Germany (Engel et al. 2014) and Austria (Hochbichler et al. 2015). In France, the rotation age for saw$\log$ production is 40 years and decreases to 25 years for the production of vineyard poles (coppice stands) (Pagès 1986; Bousse and Richard 2017).

2. Production (fertility) class (and correlated type of wood product): it ranges between 20 and 25 years in the lowest production classes (V in Romania, VI in Hungary, for poles, props, pulp, other small-size industrial wood) and 35-40 years in the Ist class for good quality sawlogs (Rédei 1984; MAPPM 2000d).

3. Regeneration pathway this is 20-25 years in coppice stands compared with stands of seed origin (30-35 yearold plantations), as in Bulgaria (Dimitrov 2001). The rotation age in these coppice stands is similar to ones in Germany and Austria (10-30 years, Iby 1997; Ruhm 2013; Engel et al. 2014; Meyer-Münzer et al. 2015) as well as in Slovenia (15-20 years in the western part of the country, Kadunc 2016, and 20-30 years in the south, Čarni et al. 2016).

Finally, there are countries like Croatia and Poland where the rotation age is not dependant on any criterion but legally fixed at 35-40 years (Poland, Zajączkowski 
2013; Zajączkowski and Wojda 2014) or 40 years (Croatia, Croatian Forests Ltd. 2016).

\section{Silviculture of black locust stands for wood production}

\section{Natural regeneration}

As mentioned earlier, natural regeneration of black locust is primarily by root suckers. The species is also regenerated, on a much smaller scale, by stool shoots and by seed.

When the rotation age has been reached, the main silvicultural system used in black locust stands in Hungary, Romania, Bulgaria, Croatia, France, Germany, Poland, and Slovenia is simple (low) coppice, considered the most cost-effective management system (Sitzia et al. 2016). This creates light-abundant sites suitable for the vegetative (and generative) regeneration of black locust (Radtke et al. 2013). After the cut, the stools are (1) left to produce adventitious or proventitious sprouts, or (2) dug out, followed by ploughing/scarification to wound shallow roots to promote root suckers (Romania, MAPPM 2000c; Bulgaria, Kostov and Alexandrov 2018; Germany, MeyerMünzer 2015; Ukraine, Lavnyy pers.comm.) (Fig. 1).

This method is cheap and efficient, allowing local people (e.g., from Romania) to collect the stool wood, which is highly valued as firewood. After the third coppice cut at about 90 years of age, after which the sprouting potential—and so the economic viability—decreases (e.g. Table 7), and the proportion of heart rot increases, all black locust stools are removed and the stand is regenerated by planting (Iby 1997; MAPPM 2000c).

\section{Artificial regeneration}

Black locust may be established by planting using reproductive material collected in certified/selected seed stands and seed orchards. These exist in Hungary, Bulgaria, Romania, Germany, Italy, Belgium, Czech Republic, Slovakia, Croatia, Bosnia and Herzegovina, FYR of Macedonia, Poland, and Ukraine (Cvjetkovic pers.comm.; Đodan pers.comm.; MMPRNP-ICAS 2012; Executive Forest Agency 2014; http:// ec.europa.eu/forematis; Lavnyy pers.comm.; Mandžukovski pers.comm.). When no local seed sources exist (for example in the case of France where establishment of a seed orchard is in progress, or in Austria), seeds are imported, mostly from other European countries (e.g., Hungary, Romania, Bulgaria), rather than from the United States (Bastien pers. comm.; Pötzelsberger pers.comm.).

The seeds are light and the yield from $100 \mathrm{~kg}$ of pods is $20 \mathrm{~kg}$ (Haralamb 1967; Rédei et al. 2001; Rédei 2013a). Because the heavy, thick and impermeable seed coat restricts germination, the seeds need pre-treatment to remove seed dormancy. In both native range (Olson 1974; Harlow et al. 1986) and in Europe (Bîrlănescu and Belu 1968; Costea et al. 1969; Savill 2013; Jastrzębowski et al. 2017; Pedrol et al. 2017), mechanical scarification using rotary tools or electric grinders, soaking in concentrated or diluted sulphuric acid, soaking in boiling or nearly boiling $\left(70-80^{\circ} \mathrm{C}\right)$ water, using low liquid nitrogen or high temperatures in an incubator are the usual methods. After appropriate pre-sowing treatment, germination rates can be as high as $85.0 \pm 5.8 \%$ (Kheloufi et al. 2018) or 89.0-100\% (Cierjacks et al. 2013; Vuković et al. 2013).

Seeds are sown in bare-root nurseries from late April to early May to avoid late frosts. The minimum distance between rows is $35-40 \mathrm{~cm}$ (Costea et al. 1969; Keresztesi $1988)$ and $2-3 \mathrm{~g}$ of seeds are used per $\mathrm{m}^{2}$ with a sowing depth of 2-4 cm (5-6 cm on sandy soils prone to excessive summer warming) (Rubțov 1958; Vakulyuk and (a)

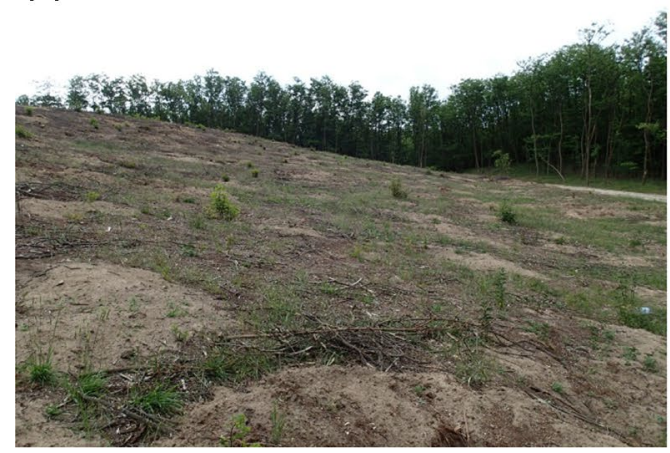

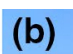

(b)

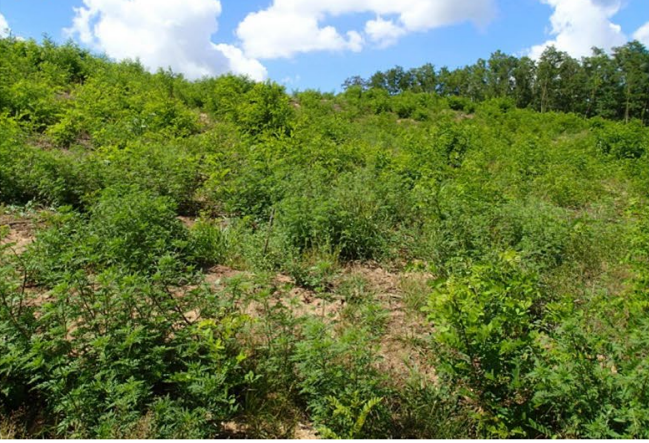

(c)

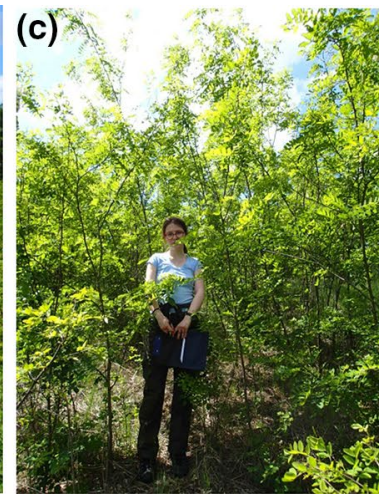

Fig. 1 Black locust stand a immediately after removal of stools, b two months and c 2 years afterwards on continental sand dunes in Romania (photos V.N. Nicolescu) 
Samoplavskyy 1998; Iancu 1999). The bare-root seedlings are ready for planting in 1 year after reach a minimum 6-mm root collar diameter and 50-200 cm in height (Iancu 1999; Rédei 2013a). In addition, artificial regeneration of black locust using plants originating from root cuttings as well as in vitro micropropagation (tissue culture) is carried out in Hungary, Bulgaria, and Poland for the reproduction of superior individuals or varieties, such as the 'shipmast' locust Robinia pseudoacacia var. rectissima Raber, with a very straight bole, extremely durable wood, and resistance to fungal diseases and insect pests, and Robinia pseudoacacia f. semperflorens (Carr) Voss. (up to five blooming periods during a vegetation season) (Keresztesi 1988; Kalmukov 2000, 2012; Szyp-Borowska et al. 2016).

The initial stocking density of black locust plantations for timber production in Europe is highly variable and ranges from 1100 to over 5000 plants ha $^{-1}$ (Table 8).

The distance between rows should be wider than that between the seedlings in the row, approximately $2.5-3.0 \mathrm{~m}$ to allow for mechanical cultivation (Austria, Ruhm 2013; Bulgaria, Ministry of Agriculture and Food 2013; France, French Ministry of Agriculture 2018; Croatia, Đodan pers. comm.).

Black locust is usually planted as a monoculture. However, mixed plantations have been recorded: black locust with hybrid/native poplars (Populus spp.) in Hungary (Rédei et al. 2002), and Serbia (Andrašev et al. 2015), with silver lime (Tilia tomentosa Moench.) and European cornel (Cornus mas L.) in Bulgaria (Kalmukov 2005), with poplars and hybrid walnut (Juglans x intermedia) in France (Gavaland and Pagès 2007), with pedunculate oak, common ash (Fraxinus excelsior L.), and sweet cherry (Prunus avium L.) in Ukraine (Lavnyy pers.comm.), with pines (Pinus spp.), oaks or maples (Acer spp.) in Germany (Carl 2018), as well as with honey locust (Gleditsia triacanthos L.), black cherry (Prunus serotina Ehrh. Fig. 2), Siberian elm (Ulmus pumila L.), and different shrubs in Romania (Spîrchez et al. 1962; MAPPM 2000a).

Protection, either for individual trees or stands using tubes, grids, or fencing (a minimum height of $1.5 \mathrm{~m}$ ), is recommended in some countries (Austria, Bulgaria, France, Germany), and is necessary when regenerating black locust

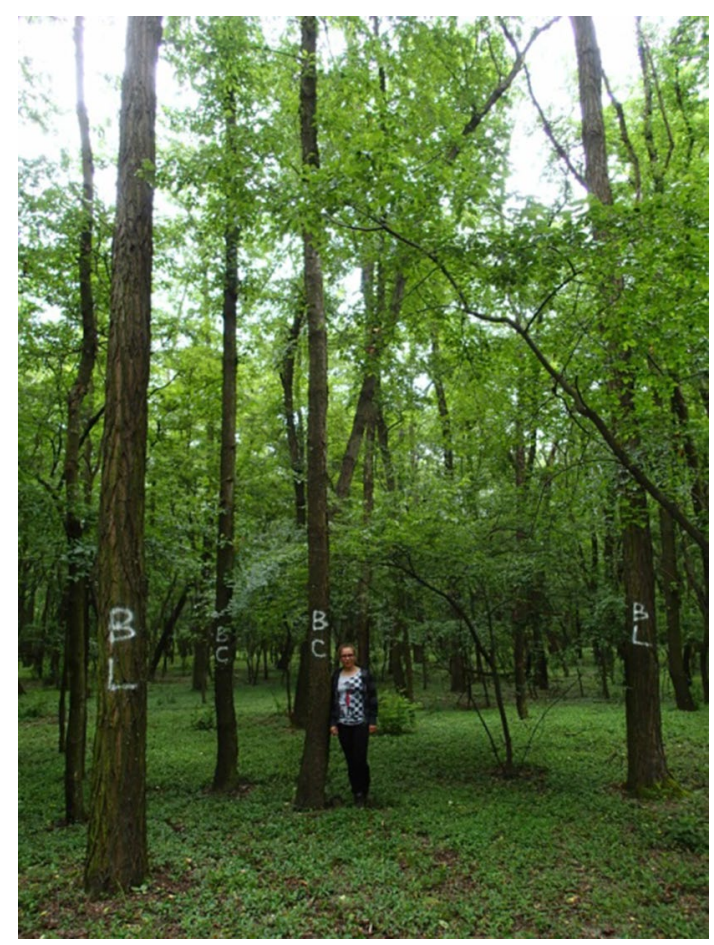

Fig. 2 Mixed black locust (BL)-black cherry (BC) stand in Romania (photo V.N. Nicolescu)

Table 8 The initial stocking of black locust plantations for timber production in different European countries

\begin{tabular}{|c|c|c|c|}
\hline $\begin{array}{l}\text { Initial stocking } \\
\left(\text { plants } \mathrm{ha}^{-1}\right)\end{array}$ & Initial spacing $(\mathrm{m})$ & Country & Source \\
\hline $1100-1900$ & & France (Bourgogne Region) & Borde (2011) \\
\hline $1200-1700$ & $4 \times 2 ; 3 \times 2$ & $\begin{array}{l}\text { France (Aquitaine and Poitou- } \\
\text { Charentes Regions) }\end{array}$ & $\begin{array}{l}\text { Carbonnière et al. (2007), CRPF (2007) and } \\
\text { French Ministry of Agriculture (2018) }\end{array}$ \\
\hline $1700-2500$ & $3 \times 2 ; 2 \times 2$ & France (Bourgogne Region) & CRPF Bourgogne (2014) \\
\hline $2000-2500$ & $2.5 \times 2 ; 2.5 \times 1.6$ & Poland & Zajączkowski (2013) and Wojda et al. (2015) \\
\hline 2500 & $3 \times 1.3$ & Croatia & Đodan pers.comm. \\
\hline 2500 & & Germany & Meyer-Münzer et al. (2015) \\
\hline $2500-3300$ & $2.0 \times 1.4-2.0$ & Austria & Hochbichler et al. (2015) \\
\hline $2500-4000$ & & Serbia & Andrašev pers.comm. \\
\hline $3300-5000$ & $(2.0-3.0) \times(1-1.5)$ & Bulgaria & Ministry of Agriculture and Food (2013) \\
\hline $4000-5000$ & $2 \times 1.25 ; 2 \times 1$ & Romania & MAPPM (2000a) \\
\hline $4000-5000$ & $2.4 \times(0.7-0.8) ; 2.4 \times 1.0$ & Hungary & Rédei et al. $(2008,2011)$ and Rédei (2013a) \\
\hline 8900 & $1.5 \times 0.75$ & Ukraine & Lavnyy pers.comm. \\
\hline
\end{tabular}


in areas with high browsing pressure (e.g., hares, roe deer, red deer as well as domestic goats or cattle) (Iby 1997; Ministry of Agriculture and Food 2013; Meyer-Münzer et al. 2015; Lemonnier Nursery 2018).

After 2-3 coppice cycles, growth depression with a reduction of timber production and an increase of heart rot have been observed (Berthold et al. 2005; Borde 2011; Meyer-Münzer et al. 2015; Vítková et al. 2016). Standard practice in some European countries (e.g. Austria, Romania, Bulgaria, Germany) is for planted trees to be coppiced three times, after which stools are removed and the stand regenerated by planting (Iby 1997; MAPPM 2000c; Dimitrov 2001; Meyer-Münzer et al. 2015). In France, black locust coppice stands are managed with four or even five coppice cycles (Borde 2011). However, when the state of coppice stands is poor, they may be clearcut and replanted after only one or two coppice cycles in order to restore the production potential.

\section{Young stand management}

Widely-spaced plantations do not require any release cuttings but one-two interventions, on a cycle of 1-3 years are necessary in stands vegetatively regenerated from root suckers or stool shoots, targeting the removal of badly shaped or forked trees ('wolves') as well as to favour root suckers over stump shoots (Haralamb 1967; Debenne 1988; MAPPM 2000b; Meyer-Münzer et al. 2015). However, such interventions are costly, particularly as the wood removed is not marketable. Therefore, combined with the high natural mortality in young root sucker-originating stands, which can be up to $70 \%$ in the first 5 years (Pagès 1985, in Carbonnière et al. 2007), these interventions are not recommended in countries like France (Carbonnière et al. 2007; Borde 2011).

At ages 4-5, the first cleaning-respacing (mostly negative selection) is performed to remove defective stems (i.e., forked, badly shaped, wounded, or bent-over as an effect of strong phototropism), to reduce the number of shoots per stool, adjust the spacing between root suckers and reduce stocking to a maximum of $2500 \mathrm{stems} \mathrm{ha}^{-1}$ (Zajączkowski 2013; Wojda et al. 2015). After 3-4 years, this is followed by second cleaning-respacing, mostly based on positive selection, with the same aims but especially to reduce stocking to ca. 1700 or even 2000 stems ha $^{-1}$, with spacing as regular as possible to provide additional growing space to the remaining individuals (Constantinescu 1976; Halupa and Rédei 1988; Rédei et al. 2011; Wojda et al. 2015).

A more intensive approach is practiced in France, with much lower initial stocking of plantations (Table 8) which is reduced, after the second cleaning-respacing, to 1000-1200 stems $\mathrm{ha}^{-1}$. In addition, extraction racks of 3-4 m wide, and at $10 \mathrm{~m}$ intervals are considered necessary due to the high stocking of young stands. These are opened during the first cleaning-respacing operation (Debenne 1988; Carbonnière et al. 2007; CRPF 2007).

The wood volume removed by cleaning-respacing may be 4-6 $\mathrm{m}^{3} \mathrm{ha}^{-1}$ (first intervention) and $15-20 \mathrm{~m}^{3} \mathrm{ha}^{-1}$ (second intervention), depending on the site potential and productivity class (Rédei 1984). The correct application and timing of cleaning-respacing is the key to good management (Halupa and Rédei 1988). If this intervention is too late or too light, the remaining trees do not develop their crowns normally and they are deformed or too small, as black locust is a strong light-demanding species. The crowns do not recover no matter how much light is subsequently available (Haralamb 1967; MAPPM 2000b).

\section{Commercial thinning}

In black locust stands, early, selective, moderate and frequent thinning is undertaken. The operations are carried out at 5-7 years intervals and are either mixed as in Romania (Costea et al. 1963; MAPPM 2000b) or from above as in Austria (Hochbichler et al. 2015), Germany (Vor pers. comm.), France (Borde 2018) and Slovenia (Čarni et al. 2016). Thinning aims to keep the crowns of the final crop trees (e.g., those which are cylindrical, with straight grain, monopodial growth, and healthy dense foliage) free from competition to encourage vigorous growth to reach the target diameter as soon as possible (Borde 2018; Vor pers.comm.). During thinning from above, 2-3 (CRPF Bourgogne 2014), 2-4 (Hochbichler et al. 2015) or a minimum of 4-5 (Borde 2018) of the strongest competitors are removed for each final crop tree. It is advisable to keep the viable trees in the lower (IV and K) Kraft classes as these contribute to the natural pruning of dominant black locust trees and reduce the danger of epicormics by shading the trunks of the most valuable individuals in the upper classes (Bîrlănescu and Clonaru 1960).

The intensity of each thinning intervention is generally between 15 and $25 \%$ of the standing volume, although the volume removed per intervention varies between different European countries and ranges from 18 to $30 \mathrm{~m}^{3} \mathrm{ha}^{-1}$ in Croatia (Đodan pers.comm.), $20 \mathrm{~m}^{3} \mathrm{ha}^{-1}$ in Serbia (Andrašev pers.comm.), $30-50 \mathrm{~m}^{3} \mathrm{ha}^{-1}$ in Hungary (Rédei 1984) to $80 \mathrm{~m}^{3} \mathrm{ha}^{-1}$ in Germany (Lockow and Lockow 2015). In countries like Hungary and Bulgaria, 25-35\% of the total wood production is removed during thinning operations (Rédei 2013c). In Hungary, the thinning intensity is determined on the basis of the "growing space index", calculated as the mean distance between trees $\times 100$ /mean stand height after thinning. This should be $23-24 \%$ in pure black locust stands (Rédei 1984; Rédei 2013c).

Generally, the number of trees per ha after the last thinning equals the stocking at rotation age and ranges between 120 and 150 stems in Austria (Hochbichler et al. 2015) and 
Table 9 Stocking of pure black locust stands after the last thinning/at rotation age in some European countries

\begin{tabular}{llll}
\hline $\begin{array}{l}\text { Number of trees after last thin- } \\
\text { ning/at rotation age }\left(\mathrm{ha}^{-1}\right)\end{array}$ & Country & Source & Obs. \\
\hline $120-150$ & Austria & Hochbichler et al. (2015) & Sawlog production \\
$150-200$ & France & Borde (2018) & Sawlog production \\
$150-300$ & France & CRPF Bourgogne (2014) & Sawlog production \\
Ca. 200 & France & Borde (2011) & Sawlog production \\
300 & Italy & Maltoni et al. (2012) & Sawlog production \\
400 & Germany & Meyer-Münzer et al. (2015) & Sawlog production \\
$400-500(600)$ & Hungary & Rédei et al. (2017) & Sawlog production \\
$400-700$ & Poland & Wąsik pers.comm. & \\
500 & France & CRPF Aquitaine (2018) & Vine stake production \\
$700-800$ & Italy & Maltoni et al. (2012) & Pole and prop production \\
& & &
\end{tabular}

700-800 stems in Italy (Maltoni et al. 2012), depending on the country and intended range of final products (Table 9).

\section{Pruning}

The terminal shoot of black locust may be repeatedly affected by frosts, causing forking multiple. Rectifying this by formative pruning (shaping) is an intervention-to-waste so is not advisable.

Green high pruning is tolerated well by black locust (Halupa and Rédei 1988) and is carried out only on crop trees, from 120 to 160 individuals ha ${ }^{-1}$ in Austria (Pötzelsberger pers.comm.) to 300/400-600 individuals $\mathrm{ha}^{-1}$ in France (Merzeau et al. 2008; CRPF 2011). This is completed in two or three lifts and stems are cleared of branches to a height of 4-6/7 m (Halupa and Rédei 1988; Rédei et al. 2017; CRPF Aquitaine 2018) or even 6-8 m (Dancart 2019). The crown length after pruning should be at least a third of the tree height (Meyer-Münzer et al. 2015).

\section{Conclusions}

Black locust is a light-demanding, competition-intolerant, fast-growing and relatively tall tree species, able to adapt to difficult site conditions (e.g., dry climates, with nutrient poor and dry soils). It is an important multipurpose species with major economic, ecological and social roles for producing wood, fodder, honey, a source of bio-oil, for biomass production and carbon sequestration, soil stabilization/ erosion control, re-vegetation of landfills, mining areas and wastelands, in biotherapy, and in landscaping. It grows rapidly when young, and height, diameter and volume growth peak before the age of 20 years. It is wind-firm, not affected by any major pest or disease, and coppices easily. Consequently black locust has a simple silvicultural management regime, clearcutting with regeneration either naturally from root suckers or stool shoots, or by planting, with the aim of producing valuble wood with various end-uses, from parquet, veneer, furniture, barrel staves, vineyard stakes to firewood, under short rotation periods of up to 40-50 years compared to major European native broadleaved tree species such as oaks and European beech.

As its potential to adapt to predicted climate changes, particularly drought, seems to be high, the importance of black locust, a species both "beloved and despised" (Vítková et al. 2017) in Europe, is expected to increase in the future. However, not only will its importance increase under expected climate conditions, but also its invasiveness potential. This reality necessitates a more complex, integrated approach to the management of such controversial species, i.e., largescale use or tolerance in forest stands in areas of economic importance, and strict eradication in other, ecologically valuable or sensitive sites.

Acknowledgements This paper is an output from the European COST Action FP1403 'Non-native tree species for European forests-experiences, risks and opportunities' (NNEXT) which was active 2014-2018. The authors also acknowledge helpful suggestions from the reviewers and the editor.

Open Access This article is licensed under a Creative Commons Attribution 4.0 International License, which permits use, sharing, adaptation, distribution and reproduction in any medium or format, as long as you give appropriate credit to the original author(s) and the source, provide a link to the Creative Commons licence, and indicate if changes were made. The images or other third party material in this article are included in the article's Creative Commons licence, unless indicated otherwise in a credit line to the material. If material is not included in the article's Creative Commons licence and your intended use is not permitted by statutory regulation or exceeds the permitted use, you will need to obtain permission directly from the copyright holder. To view a copy of this licence, visit http://creativecommons.org/licenses/by/4.0/.

\section{References}

Andrašev S, Bobinac M, Rončević S (2015) Elements of growth and characteristics of the first thinning in the mixed culture of poplar and black locust on fluvisol. In: Kovačević D (ed) Proceedings 
of the sixth international scientific agricultural symposium "Agrosym 2015". University of East Sarajevo, Faculty of Agriculture, Sarajevo, pp 2088-2094

Anko B (1989) Forest order for Illyrian Provinces in 1810. Ljubljana: Viri za zgodovino gozda in gozdarstva na Slovenskem, vol 5, p 129 (in Slovenian)

Anonymous (1987) Regulatory and reference materials for the forest measurement in Ukraine and Moldova. Urozhaj, Kyiv, p 560 (in Russian)

Anonymous (2017a) The final report of the research topic "Ecological, economic and management consequences of the occurrence of selected species of alien trees in Poland", implemented by Laboratory of Dendrometry and Forest Productivity in 2013-2017, under contract of General Directorate of Polish State Forests in Warsaw. Polish State Forests, Warszawa, p 285 (in Polish)

Anonymous (2017b) Report on the Forest Sector of the Slovak Republic 2016 - green report. Ministry of Agriculture and Rural Development of the Slovak Republic, Bratislava. http://www.mpsr.sk/. Accessed 5 Oct 2018

Aslam AJ (2015) Stress responses of black locust (Robinia pseudoacacia L.) to drought and/or pathogen attack. Ph.D. dissertation. Department of Biology, University of Hamburg, Hamburg, p 143

Banković S, Medarević M, Pantić D, Petrović N (2009) The National Forest Inventory of the Republic of Serbia: the growing stock of the Republic of Serbia. Ministry of Agriculture, Forestry and Water Management of the Republic of Serbia. Forest Directorate, Belgrade, p 238 (in Serbian)

Benčat T (1989) Black locust biomass production in Southern Slovakia. Acta dendrobiologica, VEDA, Bratislava, p 192

Benesperi R, Giuliani C, Zanetti S, Gennai M, Mariotti Lippi M, Guidi T, Nascimbene J, Foggi B (2012) Forest plant diversity is threatened by Robinia pseudoacacia (black-locust) invasion. Biodiv Cons 21:3555-3568

Berthold D, Vor T, Beese F (2005) Soil degradation by Robinia pseudoacacia L. (Black Locust) in Hungary. In: Nentwig W, Bacher S, Cock MJW, Dietz H, Gigon A, Wittenberg R (eds) Biological invasions: from ecology to control, vol 6. Neobiota, Berlin, pp $67-78$

Bîrlănescu E, Belu C (1968) Culture of black locust, focusing on black locust culture in Oltenia. In: Bakoș V (ed) Culture of fast growing tree species. Editura agrosilvică, București, pp 332-346 (in Romanian)

Bîrlănescu E, Clonaru A (1960) Contributions to the influence of thinning on black locust stands. Effects of a heavy intervention. Rev păd 12:738-741 (in Romanian)

Bîrlănescu E, Costea A (1962) Research on black locust regeneration on sandy soils in the south of Oltenia. Institutul de Cercetări Forestiere, Studii și Cercetări, XXII(C), pp 19-33 (in Romanian)

Bîrlănescu E, Costea A, Stoiculescu C (1966) A new variety of black locust identified in Romania-Robinia pseudacacia L. var oltenica Birl. Bost et Stoic Rev păd 9:483-486 (in Romanian)

Bîrlănescu E, Diaconu M, Costea A, Cojocaru I (1977) Research on black locust (Robinia pseudoacacia L.) improvement. ICAS București St Cerc 34:41-54 (in Romanian)

BMEL (2014) Forest in Germany: selected results from the 3rd National Forest Inventory. BMVEL (Bundesministerium für Verbraucherschutz, Ernährung und Landwirtschaft), Berlin, $p$ 52 (in German)

Boer E (2013) Risk assessment Robinia pseudoacacia L. Naturalis Biodiversity Center, Leiden, p 18

Borde B (2011) Black locust in Bourgogne. Silviculture and management guidelines. Centre Régional de la Propriété Forestière de Bourgogne, Chalons sur Saône, p 19 (in French)

Borde B (2018) Developing a black locust silviculture producing sawlogs. For-ent 241:12-15 (in French)
Boring LR, Swank WT (1984) The role of black locust (Robinia pseudoacacia) in forest succession. J Ecol 72:749-766

Bousse M, Richard V (2017) Valorisation and uses of black locust in Occitanie. (Midi Pyrénées Bois Report). Maison de la Coopération, Auzeville Tolosane, p 16 (in French)

Branco M, Battisti A, Mendel Z (2016) Foliage feeding invasive insects: defoliators and gall makers. In: Paine TD, Lieutier D (eds) Insects and diseases of mediterranean forest systems. Springer, Cham, pp 211-238

Branquart E, Vanderhoeven S, Van Landuyt W, Van Rossum F, Verloove F (2007) Invasive alien species in Belgium: Robinia pseudoacacia-Black locust. https://ias.biodiversity.be/species/ show/15. Accessed 20 Oct 2018

Brosse J (1977) Trees of Western Europe. Bordas éditions, Paris, p 239 (in French)

Brus R (2011) Dendrology for foresters. Univerza v Ljubljani, Biotehniška fakulteta, Ljubljana, p 408 (in Slovenian)

Brus R, Ficko A, Roženbergar D, Westergren M, Jarni K (2016) Slovenia. In: Hasenauer H, Gazda A, Konnert M, Mohren G, Pötzelsberger E, Spiecker H, van Loo M (eds) Non-native tree species for European Forests: experiences, risks and opportunities. COST Action FP1403 NNEXT Country Reports, Joint Volume. University of Natural Resources and Life Sciences (BOKU), Vienna, pp 297-304

Carbonnière T, Debenne JN, Merzeau D, Rault M (2007) Black locust in Aquitaine. For-ent 177:13-17 (in French)

Carl C (2018) Short portrait black locust (Robinia pseudoacacia L.). https://www.waldwissen.net/waldwirtschaft/waldbau/ wuh_robinie/index_DE. Accessed 8 Oct 2018 (in German)

Čarni A, Brus R, Dakskobler I, Juvan N, Kutnar L, Marinšek A (2016) Planning and silvicultural intervention in situations of the presence of non-native invasive species. Znanstvenoraziskovalni center Slovenske akademije znanosti in umetnosti, Ljubljana, p 151 (in Slovenian)

Čavlović J (2010) First national forest inventory of Croatia. Ministarstvo regionalnog razvoja šumarstva i vodnoga gospodarstva, Šumarski fakultet Sveučilišta u Zagrebu, Zagreb, p 31 (in Croatian)

Cierjacks A, Kowarik I, Joshi J, Hempel S, Ristow M, von der Lippe M, Weber E (2013) Biological Flora of the British Isles: Robinia pseudoacacia. J Ecol 101:1623-1640

CIRAD (2012) Black locust wood characteristics. https://tropix.cirad .fr/FichiersComplementaires/FR/Temperees/ROBINIER.pdf. Accessed 8 Oct 2018 (in French)

Ciuvăț AL, Blujdea V, Abrudan IV, Nuță IS, Negruțiu F (2015) Ecosystem services provided by black locust (Robinia pseudacacia L.) plantations in south-western Romania. In: Proceedings of the Biennial international symposium forest and sustainable development, Brașov, October 2014. Transylvania University of Brașov, Brașov, pp 151-156

Claessens H, Alderweireld M, Thibaut A (2006) Potentialities of black locust in Wallonia. For Wall 84:30-39 (in French)

Constantinescu N (1976) Tending of forest stands, vol II. Editura Ceres, București, p 402 (in Romanian)

Contu S (2012) Robinia pseudoacacia. The IUCN red list of threatened species 2012: e.T19891648A20138922. http://dx.doi. org/10.2305/IUCN.UK.2012.RLTS.T19891648A20128922. en. Accessed 5 Oct 2018

Costea A, Bîrlănescu E, Belu C (1963) Black locust culture. Rev păd 6:325-329 (in Romanian)

Costea A, Lăzărescu C, Bîrlănescu E, Ivanschi T, Armășescu S, Gr Trantescu, Latiș L, Pîrvu E (1969) Recommendations on black locust culture. ICSPS, București, p 38 (in Romanian)

Crăciunescu G (1904) Afforestation of flying sands from the PiscuTunari and Ciuperceni State estates, Doljiu County. Rev păd 2:202-210 (in Romanian) 
Croatian Forests Ltd (2016) National Forest Management Plan 20162025. Ministry of Agriculture, Zagreb, p 927 (in Croatian)

Crosti R, Agrillo E, Ciccarese L, Guarino R, Paris P, Testi A (2016) Assessing escapes from short rotation plantations of the invasive species Robinia pseudoacacia L. in Mediterranean ecosystems: a study in central Italy. iFor Bio For 5:822-828

CRPF (2007) The black locust. Centre Régional de la Propriété Forestière de Poitou-Charentes, Smarves, p 4 (in French)

CRPF (2011) Black locust. FOGEFOR du Limousin, Limoges, p 2 (in French)

CRPF Aquitaine (2018) Black locust (Robinia pseudoacacia L.). CPFA Maison de la Forêt et de l'Agriculture, Bordeaux, p 4 (in French)

CRPF Bourgogne (2014) Black locust, a tree to discover. CRPF, Chalons sur Saône, p 6 (in French)

CRPF Nord Pas-de-Calais Picardie (2015) Black locust, wood quality and silviculture in Picardie. CRPF, Amiens, p 7 (in French)

Cseresnyés I, Csontos P (2012) Soil seed bank of the invasive Robinia pseudoacacia in planted Pinus nigra stands. Acta Botanica Croatica 2:249-260

Dancart D (2019) Black locust. Silv Bel 4:40-49 (in French)

Debenne JN (1988) Black locust, a short rotation species indispensable in the rural areas. For de Fr 314:29-31 (in French)

DeGomez T, Wagner MR (2001) Culture and use of black locust. HortTech 2:279-288

Demené JM, Merzeau D (2007) Black locustHistory and biological characteristics. For-ent 177:10-12 (in French)

Dimitrov E (2001) Studies on the ecological, biological and silvicultural characteristics of black locust in northeastern Bulgaria. Summary of dissertation. Forest Research Institute, Bulgarian Academy of Sciences, Sofia, p 56. (in Bulgarian)

Dimitrova P (2012) Assesment of the introduction of black locust (Robinia pseudoacacia L.) in Bulgaria. Nauka za Gorata 1(2):71-82 (in Bulgarian)

Đodan M, Brus R, Eisold AM, Nicolescu VN, Oršanić M, Pratasiene K, Perić S (2018) Non-native tree species in the viewpoint of climate change: chances and opportunities-Croatia as a case study. Šumarski list 7-8:391-402

Donchev J (1968) About several basic aspects during establishment of black locust (Robinia pseudoacacia L.) plantations, vol 16. Scientific Reports of Forestry University, Forestry, Sofia, pp 53-61 (in Bulgarian)

Drăcea MD (1919) When and on what pathway the black locust came to us? Eco For 3-4:71-75 (in Romanian)

Duso C, Fontana P, Tirello P (2005) Spread of the gall midge Obolodiplosis robiniae (Haldeman) injurious to black locust in Italy and Europe. Informatore Fitopatologico 5:30-33 (in Italian)

Dyderski MK, Paź S, Frelich LE, Jagodziński AM (2017) How much does climate change threaten European forest tree species distributions? Glob Change Biol 24:1150-1163

Enescu CM, Dănescu A (2015) Black locust (Robinia pseudoacacia L.) - an invasive neophyte in the conventional land reclamation flora in Romania. Bull Trans Univ Braşov Ser II For Wood Ind Agric Food Eng 6:23-30

Engel J, Knoche D, Lange C (2014) Recommendations to manage black locust stands. https://www.waldwissen.net/waldwirtschaft/waldb au/betriebsarten/lfe_robinienwirtschaft/index_DE. Accessed 5 April 2018. Landesbetrieb Forst Brandenburg, Potsdam (in German)

Erdélyi G (1988) Wood utilization. In: Keresztesi B (ed) The black locust. Akadémiai Kiadó, Budapest, pp 135-150

Evans J (1984) Silviculture of broadleaved woodland, vol 62. Forestry Commission Bulletin, HMSO, London, p 232
Executive Forest Agency (2014) National list of approved basic material. Sofia, Bulgaria. http://www.iag.bg/docs/lang/2/cat/7/index . Accessed 7 Oct 2018

Executive Forest Agency (2015) Balance of forest areas to 31/12/2015, form 2. Executive Forest Agency, Sofia (in Bulgarian)

Facciotto G, Nervo G, Vietto L (2008) Biomass production with fast growing woody plants for energy purposes in Italy. ASO Funded Project Workshop 'Increased biomass production with fast-growing tree species in short rotation forestry: impact of species and clone selection and socio-economic impacts'. Sofia, Bulgaria, 17-21 Nov 2008. University of Forestry, Sofia

Feliksik E, Orzeł S, Wilczyński S (2007) Dendrometric and dendroclimatological analyses of Black locust. EJPAU 2:7

Filipas M (2013) Soil seed bank in black locust (Robinia pseudoacacia L.) stands at Medvednica Mt. and Maksimir Park. Master thesis, Faculty of Science, University of Zagreb, Zagreb, p 28 (in Croatian)

Forest Europe (2015) State of Europe's Forests 2015. Ministerial Conference on the Protection of Forests in Europe, FOREST EUROPE Liaison Unit Madrid, p 312

French Ministry of Agriculture (2018) Guidelines on the use of forest genetic resources-Robinia pseudoacacia. http://agricultur e.gouv.fr/telecharger/82268?token=f8e5aa3f2fc69e7943a1e0b04 5b2e656. Accessed 7 Oct 2018 (in French)

Gavaland A, Pagès L (2007) Black locust for biomass production and in association with valuable hardwoods in plantation. For-Ent 177:26-29 (in French)

Giuliani C, Lazzaro L, Mariotti Lippi M, Calamassi R, Foggi B (2015) Temperature-related effects on the germination capacity of black locust (Robinia pseudoacacia L., Fabaceae) seeds. Folia Geobotanica 50:275-282

Giulietti V (2016) Robinia (Robinia pseudoacacia L.). In: Bonari E, Maracchi G (eds) Le biomase lignocellulosiche. Firenze University Press, Firenze, pp 163-170 (in Italian)

Giurgiu V, Drăghiciu D (2004) Mathematical-growth models and yield tables of stands. Editura Ceres, București, p 607

Glavaš M (1999) Fungal diseases of forest trees. Sveučilište u Zagrebu, Šumarski fakultet, Zagreb, p 281 (in Croatian)

Gras M (1991) Robinia pseudoacacia L. Annotations from a bibliographic review. SAF, RESS S.p.A, Roma, p 59 (in Italian)

Gras M, Mughini G (2009) Robinia pseudoacacia L. In: Ducci F, de Rogatis A (eds) Risorse Genetiche Forestali in Italia (chapter 4). CRA SEL-Centro di Ricerca per la Selvicoltura, Arezzo, pp 1-4 (in Italian)

Grünewald H, Böhm C, Quinkenstein A, Grundmann P, Eberts J, von Wühlisch G (2009) Robinia pseudoacacia L.: a lesser known tree species for biomass production. BioEnergy Res 2:123-133

Halupa L, Rédei K (1988) Forest tending. In: Keresztesi B (ed) The black locust. Akadémiai Kiadó, Budapest, pp 115-125

Hanover JW (1990) Physiological genetics of black locust (Robinia pseudoacacia L.): a model multipurpose tree species. In: Werner $\mathrm{D}$, Muller P (eds) Fast growing trees and nitrogen fixing trees. International conference, Marburg, 8-12 October 1989. Gustav Fischer Verlag, Stuttgart-New York, pp 175-183

Haralamb AT (1967) Culture of tree species. Editura Agro-silvică, București, p 755 (in Romanian)

Harlow WM, Harrar ES, White FM (1986) Textbook of dendrology, 6th edn. McGraw-Hill Book Company, New York, p 510

Hemery G, Simblet S (2014) The New Sylva. A discourse of forest and orchard trees for the twenty-first century. Bloomsbury Group, London, p 390

Herman J (1971) Forest dendrology. Stanbiro, Zagreb, p 470 (in Croatian)

Hochbichler E, Baumgartner L, Schuster K, Starlinger F, Englisch M, Hagen R, Wolfslehner G (2015) Silvicultural recommendations for forest management in Lower Austria. Amt der NÖ 
Landesregierung, Abteilung Forstwirtschaft (LF4), St. Pölten, p 246 (in German)

Hofmann F (1861) Tree plantations in Marchfeld. Allgemeine Forst Zeit 27:833-835 (in German)

http://ec.europa.eu/forematis/. European Commission 2018 FOREMATIS web site of EU Forest Reproductive Materials. Accessed 7 Oct 2018

http://invasoras.pt/en/gallery/robinia-pseudoacacia-en. Accessed 10 Oct 2018

https://ec.europa.eu/environment/nature/natura2000/index_en.htm. Accessed 2 Jan 2020

https://www.ddg-web.de/index.php/rekordbaeume.html. Accessed 7 July 2018

https://www.iucn.org/theme/species/our-work/invasive-species/. Accessed 2 Nov 2018

https://www.monumentaltrees.com/en/trees/blacklocust/records/. Accessed 7 July 2018

Huntley JC (1990) Robinia pseudoacacia L. Black locust. In: Burns RM, Honkala BH (tech coords) Silvics of North America, volume 2, hardwoods. Agriculture handbook no. 654. Forest Service, United States Department of Agriculture, Washington, pp 755-761

Iancu I (1999) Forester's handbook-theory and practice. Tipografia Pegasus, București, p 622 (in Romanian)

Iby H (1997) Experiences with Robinia in the Pannonic area. Jahreshauptversammlung. Burgenländischer Forestverein, Eisenstadt, p 8 (in German)

Idžojtić M (2003) Hosts and distribution of the white-berried mistletoe (Viscum album L. ssp. album) in Croatia. Sumarski List 9-10:439-447 (in Croatian)

Idžojtić M, Glavaš M, Zebec M, Pernar R, Beuk P, Prgić I (2006) Intensity of infection with yellow mistletoe and white-berried mistletoe on the area of the forest administrations Vinkovci and Nova Gradiška. Sumarski List 9-10:399-409 (in Croatian)

IGN (2018) National Forest Inventory web site. https://inventaire -forestier.ign.fr/spip.php?rubrique149. Accessed 5 Oct 2018 (in French)

Iliev N, Iliev I, Park YG (2005) Black locust (Robinia pseudoacacia L.) in Bulgaria. J Kor For Soc 5:291-301

Jacquin F (1825) The University garden in Vienna. Carl Gerold, Wien, p 49 (in German)

Jardin des Plantes (2018) Tree stories. Archives. http://www.jardi ndesplantes.net/sites/jardindesplantes/files/documents/histo ires_d_arbres.pdf. Accessed 5 Oct 2018

Jastrzębowski S, Ukalska J, Kantorowicz W, Klisz M, Wojda T, Sułkowska M (2017) Effects of thermal-time artificial scarification on the germination dynamics of black locust (Robinia pseudoacacia L.) seeds. Eur J For Res 136:471-479

Jovanović B (1967) Dendrology with the basics of phytocoenology. Naučna knjiga, Beograd, p 576 (in Serbian)

Juhásová G, Hrubík P (1984) Diseases and pests of foreign woody plants in Slovakia. Acta Dendrobiologica, VEDA, Bratislava, $p$ 168 (in Slovak)

Kadunc A (2016) Growth and yield characteristics of black locust (Robinia pseudoacacia L.) in Slovenia. Gozd Vest 74:73-87 (in Slovenian)

Kalmukov K (1995) Influence of initial stocking on the process of growth and development of some fast-growing tree species used for biomass. In: Brezin V, Yovkov I, Dinkov B, Pavlova E, Vasilev V, Draganova I (eds) Proceedings of the Jubilee Scientific Session "70 years of higher forestry education in Bulgaria", Volume I "Forestry". Higher Institute of Forestry, pp 129-137 (in Bulgarian)

Kalmukov K (2000) Robinia pseudoacacia f. semperflorens, repeatedly blooming form of black locust. In: Pipkov N, Zhelev P, Draganova I (eds) Proceedings of the Jubilee scientific reports
"75 years of higher forestry education in Bulgaria", section "Forestry". Higher Institute of Forestry, Sofia, pp 356-358 (in Bulgarian)

Kalmukov K (2005) Growth and yield of pure and mixed black locust cultures. In: Proceedings of the symposium forest and sustainable development. Transylvania University of Braşov, Braşov, pp 91-96

Kalmukov K (2012) Specific characteristics of Robinia pseudoacacia var. semperflorens. Pl Stud 6:89-94 (in Bulgarian)

Kalmukov K (2014) Improvement of black locust stands in Bulgaria. Gora 6-7:24-26 (in Bulgarian)

Keresztesi B (1983) Breeding and cultivation of black locust (Robinia pseudoacacia L.) in Hungary. For Ecol Manag 6:217-244

Keresztesi B (1988a) Natural range of black locust and its distribution in other countries. In: Keresztesi B (ed) The black locust. Akadémiai Kiadó, Budapest, pp 9-17

Keresztesi B (ed) (1988b) The black locust. Akadémiai Kiadó, Budapest, p 197

Kheloufi A, Mansouri LM, Aziz N, Sahnoune M, Boukemiche S, Ababsa B (2018) Breaking seed coat dormancy of six tree species. Reforesta 5:4-14

Kirov D (1886) Annual report of Svishtov Forest inspectorate. In: Annual reports of forest inspectors for 1896. Ministry of Commerce and Agriculture, Forestry Department, State Printing House, Sofia, pp 453-477

Kitin B (1960) Growth and condition of the black locust plantations in South Dobrudzha. Scientific research papers of the Higher Institute of Forestry, Sofia, vol 8, pp 89-135 (in Bulgarian)

Kleinbauer I, Dullinger S, Peterseil F, Essl F (2010) Climate change might drive the invasive tree Robinia pseudoacacia into nature reserves and endangered habitats. Biol Conserv 143:390-392

Klisz M, Ukalska J, Wojda T, Jastrzębowski S, Mionskowski M, SzypBorowska I (2014) Radial growth of selected stands of black locust in Poland. Ann War Univ Life Sci SGGW For Wood Technol 85:123-130

Kohno MA (2007) The history of the introduction of woody plants in Ukraine: a brief sketch. Fitosotsiotsentr, Kyiv, p 67 (in Ukrainian)

Kostov G, Alexandrov N (2018) Management of coppice forests. Dijor Print, Sofia, p 84 (in Bulgarian)

Kowarik I (2011) Novel urban ecosystems, biodiversity and conservation. Environ Poll 8-9:1974-1983

Krausch HD (2001) Introduction and dispersal of black locust in Europe. Bei Gehölz, pp 107-115 (in German)

Kutnar L, Kobler A (2013) The current distribution of black locust (Robinia pseudoacacia L.) in Slovenia and predictions for the future. Act Silv Lign 102:21-30 (in Slovenian)

Lavnyy V, Savchyn V (2016) Ukraine. In: Hasenauer H, Gazda A, Konnert M, Lapin K, Mohren GMJ (Frits), Spiecker H, van Loo M, Pötzelsberger E (eds) Non-native tree species for european forests: experiences, risks and opportunities. FP 1403 NNEXT Country Reports, Joint Volume. University of Natural Resources and Life Sciences (BOKU), Vienna, pp 404-409

Lazzaro L, Mazza G, d'Errico G, Fabiani A, Giuliani C, Inghilesi AF, Lagomarsino A, Landi S, Lastrucci L, Pastorelli R, Roversi PF, Torrini G, Tricarico E, Foggi B (2018) How ecosystems change following invasion by Robinia pseudoacacia: insights from soil chemical properties and soil microbial, nematode, microarthropod and plant communities. Sci Total Environ 622-623:1509-1518

Lemonnier Nursery (2018) http://www.pepinieres-lemonnier.fr/catal ogue/index.html\#p=234. Accessed 7 Oct 2018 (in French)

Lj Mihajlović, Stanivuković Z (2009) Allochtonous insect species of forests and decorative woody species in the Republic of Srpska. Bull Fac For 11:1-26 
Lockow KW (2005) Black locust from a yield and ecological perspective. For Hol 60:450-457 (in German)

Lockow KW, Lockow J (2015) Yield table for black locust (Robinia pseudoacacia L.). Gesellschaft zur Förderung schnellwachsender Baumarten, Eutin, p 80 (in German)

Los SA, Tereshchenko LI, Gayda YI (2014) State of forest genetic resources in Ukraine. Planeta-Print, Kharkiv (in Ukrainian)

Luna RK (1996) Robinia pseudoacacia Linn. International Book Distributions, Dehra Dun, pp 633-639

Lyr H, Hoffmann G, Dohse K (1963) The influence of degrees of shading on dry matter production in young plants of some forest species. Jena Flora 153(Part 1):291-311 (in German)

Maceljski M, Mešić A (2001) Phyllonorycter robiniella Clemens, a new insect pest in Croatia. Agric Consp Sci 4:225-230 (in Croatian)

Maltoni A, Tani A, Mariotti B (2012) Black locust management in Tuscany: management of stands, use in specialized plantations, control of dispersal. Ed. Regione Toscana, Firenze, p 167 (in Italian)

Mantovani D, Freese A, Veste M (2014) Black locust (Robinia pseudoacacia L.) ecophysiological and morphological adaptations to drought and their consequences on biomass production and water-use efficiency. New Z J For Sci 29:1-11

MAPPM (2000a) Technical norms on species compositions, planting schemes and forest regeneration technologies and afforestation of degraded lands 1. Ministerul Apelor, Pădurilor și Protecției Mediului, București, p 272 (in Romanian)

MAPPM (2000b) Technical norms on tending operations 2. Ministerul Apelor, Pădurilor și Protecției Mediului, București, p 163 (in Romanian)

MAPPM (2000c) Technical norms on silvicultural systems 3. Ministerul Apelor, Pădurilor și Protecției Mediului, București, p 85 (in Romanian)

MAPPM (2000d) Technical norms on forest management 5. Ministerul Apelor, Pădurilor și Protecției Mediului, București, p 163 (in Romanian)

McAlister RH (1971) Black locust (Robinia pseudoacacia L.). U.S. Department of Agriculture, Washington. Forest Service, American Woods-FS-24, p 6

Merzeau D, Coquillas V, Bazas S (2008) Growth of black locust in Aquitaine: productivity classes. For-ENT 182:49-52 (in French)

Meyer-Münzer B, Grotehusmann H, Vor T. 2015. Black locust (Robinia pseudoacacia L.). In: Vor T, Spellmann H, Bolte A, Ammer C (eds). Potentials and risks of introduced tree species. Göttingen: Göttinger Forstwissenschaften 7, pp 277-296 (in German)

Ministry of Agriculture and Food (2013) Regulation no. 2/07.02. 2013 on the terms and procedures for afforestation of forest areas and agricultural land used for creating special, protective and commercial forests and forests in protected areas, inventory of created plantations, their accounting and registration. SG 16/19.02.2013. Ministry of Agriculture and Food, Sofia, p 40 (in Bulgarian)

MIPAAF (2017) Decree approving the national list of monumental trees. Section 1-trees whose administrative registration is complete. Ministero delle politiche agricole alimentari, forestali e del turismo, Roma, D.M.N.5440/19.12.2017. https://www.politichea gricole.it/flex/cm/pages/ServeBLOB.php/L/IT/IDPagina/11260. Accessed 7 Oct 2018

MMP-RNP-ICAS (2012) National catalogue of basic material for the production of forest reproductive materials. Ministerul Mediului și Pădurilor, Regia Națională a Pădurilor, Institutul de Cercetări şi Amenajări Silvice, București, p 282 (in Romanian)

Motta R, Nola P, Berretti R (2009) The rise and fall of the black locust (Robinia pseudoacacia L.) in the "Siro Negri" Forest Reserve (Lombardy, Italy): lessons learned and future uncertainties. Ann For Sci 4:409-410
Muller S (2004) Robinia pseudoacacia L. Black locust. In: Muller S (eds) Invasive plants in France. Muséum national d'Histoire naturelle, Patrimoins naturels, Paris, vol 62, pp 92-93 (in French)

Müller F (1990) Black locust for biomass production in short rotation plantations. Öst Forst 5:22-24 (in German)

Nadal-Sala D, Hartig F, Garcia CA, Sabaté S (2019) Global warming likely to enhance black locust (Robinia pseudoacacia L.) growth in a Mediterranean riparian forest. For Ecol Manag 449:1-14

Nasir H, Iqbal Z, Hiradate S, Fujii Y (2005) Allelopathic potential of Robinia pseudo-acacia L. J Chem Ecol 9:2179-2192

Naydenov Y (2015) About continuity and something else. Gora 5:22 (in Bulgarian)

Negulescu E, Al Săvulescu (1957) Dendrology. Editura Agro-Silvică de Stat, București, p 457 (in Romanian)

Nicolescu VN, Hernea C, Bartlett D, Iacob N (2019) Regeneration and early tending of black locust (Robinia pseudoacacia L.) stands in the north-west of Romania. S-E Eur For (SEEFOR) 2:1-9

Olenici N, Duduman ML (2016) New records of some invasive forest insect species in Romania. Buc For 2:161-174 (in Romanian)

Olson DF (1974) Robinia L. Locust. In: Schopmeyer CS (tech coord) Seeds of woody plants in the United States. Agriculture handbook no. 450. Forest Service, U.S. Department of Agriculture, Washington, pp 728-731

Pagès L (1986) Coppice biomass growth laws: black locust in Val-deLoire. Ann Sci For 4:533-550 (in French)

Paris P, Todaro L, Sacchetti R, Scarascia Mugnozza G, Pisanelli A, Cannata P (2006) Black locust for biomass plantations in marginal areas. Alb Terr 10(11):22-27 (in Italian)

Pedrol N, Puig CG, López-Nogeueira A, Pardo-Muras M, Gonzáles L, Souza-Alonso P (2017) Optimal and synchronized germination of Robinia pseudoacacia, Acacia dealbata and other woody Fabaceae using a handheld rotary tool: concomitant reduction of physical and physiological seed dormancy. J For Res 29(2):283-290

Pernek M, Matošević D (2009) Black locust gall midge (Obolodiplosis robiniae), new pest on black locust trees and first record of parasitoid Platygaster robinae in Croatia. Šum List 3-4:157-163 (in Croatian)

Pignatti S (1982) Flora of Italy, vol 3. Edagricole, Bologna, p 275 (in Italian)

Poryazov Y, Tonchev T, Dobrichov I (2004) Handbook of forest measurements. Sofia, Bulvark, p 419

Poskin A (1926) Handbook of silviculture. Librairie Agricole de la Maison Rustique, Gembloux, p 439 (in French)

Pyšek P, Lambdon PW, Arianoutsou M, Kühn I, Pino J, Winter M (2009) Alien vascular plants of Europe. In: Nentwig W (ed) Handbook of Alien Species in Europe, DAISIE. Invading nature: Springer series in invasion ecology, vol 3. Springer, Dordrecht, pp 43-61

Radtke A, Ambraß S, Zerbe S, Tonon G, Fontana V, Ammer C (2013) Traditional coppice forest management drives the invasion of Ailanthus altissima and Robinia pseudoacacia into deciduous forests. For Ecol Manag 291:308-317

Rameau JC, Mansion D, Dumé G, Gaubreville C (1989) French Forest Flora, vol 1. Ed. IDF-CNPF, Paris, p 1785 (in French)

Rédei K (1984) Yield of Black Locust Stands. FRI Research Report, Budapest, p 21 (in Hungarian)

Rédei K (2013a) Stand establishment. In: Rédei K (ed) Black locust (Robinia pseudoacacia L.) growing in $\mathrm{Hu} \Delta \Delta \Delta \Delta \Delta$ ngary. Hungarian Forest Research Institute, Sárvár, pp 27-34

Rédei K (2013b) The black locust (Robinia pseudoacacia L.) and its features. In: Rédei K (ed) Black locust (Robinia pseudoacacia L.) growing in Hungary. Hungarian Forest Research Institute, Sárvár, pp 7-11 
Rédei K (2013c) Tending and yield of black locust stands. In: Rédei K (ed) Black locust (Robinia pseudoacacia L.) growing in Hungary. Hungarian Forest Research Institute, Sárvár, pp 35-46

Rédei K (ed) (2013d) Black locust (Robinia pseudoacacia L.) growing in Hungary. Hungarian Forest Research Institute, Agroinform Kiadó, Budapest, $\mathrm{p} 78$

Rédei K, Veperdi I (2009) The role of black locust (Robinia pseudoacacia L.) in establishment of short-rotation energy plantations in Hungary. Int J Hort Sci 3:41-44

Rédei K, Osváth-Bujtás Z, Balla I (2001) Propagation methods for black locust (Robinia pseudoacacia L.) improvement in Hungary. J For Res 4:215-219

Rédei K, Ostváth-Bujtás Z, Balla I (2002) Clonal approaches to growing black locust (Robinia pseudoacacia) in Hungary: a review. Forestry 5:548-552

Rédei K, Osváth-Bujtás Z, Veperdi I (2008) Black locust (Robinia pseudoacacia L.) improvement in Hungary: a review. Act Silv Lign Hung 4:127-132

Rédei K, Csiha I, Keserú Z (2011) Black locust (Robinia pseudoacacia L.) short-rotation crops under marginal site conditions. Act Silv Lign Hun 7:125-132

Rédei K, Csiha I, Keserü Z, Végh ÁK, Györi J (2012) The silviculture of black locust (Robinia pseudoacacia L.) in Hungary: a review. S-E Eur For (SEEFOR) 2:101-107

Rédei K, Csiha I, Keserú ZS, Rásó J, Kamandiné Végh A, Antal B (2014) Growth and yield of black locust (Robinia pseudoacacia L.) stands in Nyírség growing region (north-east Hungary). S-E Eur For (SEEFOR) 1:13-22

Rédei K, Zs Keserü, Csiha I, Ráso J, Honfy V (2017) Plantation silviculture of black locust (Robinia pseudoacacia $\mathrm{L}$.) cultivars in Hungary-a review. S-E Eur For (SEEFOR) 2:151-156

Rițiu A, Nicolescu L, Nicolescu N (1988) Some considerations on windfalls and windbreaks in black locust forests in the north-west of the country. Rev păd 3:131-133 (in Romanian)

Rizzo M, Gasparini P (2011) Occurrence and distribution of alien invasive tree species in the Italian forests. For Ideas 1:97-103

Roşu C (1996) Black locust (Robinia pseudacacia L.), between legend and reality. Rev păd 4:17-20 (in Romanian)

Rubțov S (1958) Robinia pseudacacia. In: Rubțov S (ed) Growing woody species in nurseries. Editura Ceres, București, pp 285291 (in Romanian)

Rudolf S, Brus R (2006) Distribution and invasiveness of black locust (Robinia pseudoacacia L.) in northeast Slovenia. Gozd vest 64:134-140 (in Slovenian)

Ruhm W (2013) Robinia, fast growing species with low demands, but not indisputable (WWW document). waldwissen.net. https:// www.waldwissen.net/wald/baeume_waldpflanzen/laub/bfw-robin ie/index_DE. Accessed 8 Oct 2018

Sabo AE (2000) Robinia pseudoacacia invasions and control in North America and Europe. Rest Recl Rev 3:1-9

Sádlo J, Vítková M, Pergl J, Pyšek P (2017) Towards site-specific management of invasive alien trees based on the assessment of their impacts: the case of Robinia pseudoacacia. NeoBiota 35:1-34

Saunier R (2007) Black locust and the beekeepers. For-ENT 177:45 (in French)

Savill P (2013) The silviculture of trees used in British forestry, 2nd edn. CABI, Wallingford and Boston, p 280

Schneck V (2010) Black locust-breeding initiatives and regeneration methods. Agrarholz 2010. http://veranstaltungen.fnr.de/filea dmin/allgemein/pdf/veranstaltungen/Agrarholz2010/11_2_Beitr ag_Schneck.pdf. Accessed 7 Oct 2018 (in German)

Schütt P (1994) Robinia pseudoacacia Linné, 1753. In: Schütt P, Weisgerber H, Schuck H, Lang U, Stimm B, Roloff A (eds) Encyclopedia of woody species, vol 2. Wiley-VCH Verlag, Weinheim, pp 1-16 (in German)
Seeling U (1997) Black locust-only an exotic in the German forest? For Holz 52:81-86 (in German)

Šiljeg M (2017) The intensity of the attack of acacia moth miners in Zagreb. Ph.D. thesis, Faculty of Agronomy, University of Zagreb, Zagreb, p 23 (in Croatian)

Sitzia T, Cierjacks A, de Rigo D, Caudullo G (2016) Robinia pseudoacacia in Europe: distribution, habitat, usage and threats. In: SanMiguel-Ayanz J, de Rigo D, Caudullo G, Durrant TH, Mauri A (eds) European Atlas of Forest Tree Species. Publications Office of the European Union, Luxembourg, pp 166-167

Ślusarczyk T (2012) Robinia forests as a refuge for rare and threatened macrofungi. Prze Przy 2:11-41 (in Polish)

Šnjegota T, Škondrić S, Šumatiš N, Topalić-Trivunović LJ 2017. Contribution to the flora of the Robinia pseudoacacia forests in Lijevče polje. In: Book of abstracts. In: 7th international symposium of ecologists-ISEM7 4-7 October 2017 Sutomore, Montenegro, $\mathrm{p} 43$

Spîrchez Z, Răsmeriță I, Rițiu A (1962) Afforestation of sandy lands from the north-west of the country. Editura Agro-Silvică, București, p 117 (in Romanian)

Stančič L (2015) An evaluation of invasive non-native black locust (Robinia pseudoacacia) in SW Slovenia. School of GeoSciences, University of Edinburgh, Edinburgh, p 128

Stănescu V (1979) Dendrology. Editura Didactică și Pedagogică, București, p 470 (in Romanian)

Stănescu V, Şofletea N, Popescu O (1997) Wooden forest flora of Romania. Editura Ceres, București, p 451 (in Romanian)

Starfinger U, Kowarik I (2003) Robinia pseudoacacia. https://neobi ota.bfn.de/handbuch/gefaesspflanzen/robinia-pseudoacac ia.html. Accessed 8 Oct 2018 (in German)

Steinegger A, Reh M (2013) Short rotation. Landwirtschaftskammer OÖ, Linz, p 8 (in German)

Stone KR (2009) Robinia pseudoacacia. In: Laboratory FS (ed) Fire effects information system. Forst Collins, U.S. Department of Agriculture, Forest Service, Rocky Mountain Research Station. http://www.fs.fed.us/database/feis/. Accessed 5 Sept 2018

Stoyanov V (1926) Black locust-distribution, silvicultural properties, economic importance and cultivation. Ministry of Agriculture and State Property, State Printing House, Sofia, p 23 (in Bulgarian)

Straker KC, Quinn LD, Voigt TB, Lee DK, Kling GJ (2015) Black locust as a bioenergy feedstock: a review. Bio Res 8:1117-1135

Strgar V (1992) Plants and gardens in Erberg's Dol. Ljubljana, Parks-the art of designing free, pp 96-106 (in Slovenian)

Swearingen J, Bargeron C (2016) Invasive Plant Atlas of the United States. University of Georgia, Center for Invasive Species and Ecosystem Health. http://www.invasiveplantatlas.org/. Accessed 5 Sept 2018

Szyp-Borowska I, Banha C, Wojda T, Szczygieł K (2016) Micropropagation of black locust (Robinia pseudoacacia L.) and genetic stability of long-term cultivated plants. Fol For Pol 58:14-19

Tănăsescu S (1961) Some data on natural regeneration of black locust on sands in the south of Oltenia. Rev păd 9:522-525 (in Romanian)

Tănăsescu S (1967) Regarding black locust natural regeneration by seed. Rev păd 7:349-352 (in Romanian)

Thurm EA, Hernandez L, Baltensweiler A, Ayan S, Rasztovits E, Bielak K, Mladenov Zlatanov T, Hladnik D, Balic B, Freudenschuss A, Büchsenmeister R, Falk W (2018) Alternative tree species under climate warming in managed European forests. For Ecol Manag 430:485-497

Tomiczek C, Diminić D, Cech T, Hrašovec B, Krehan H, Pernek M, Perny B (2008) Pests and diseases of urban trees. Šumarski institut, Zagreb, Šumarski fakultet Sveučilišta u Zagrebu, Jastrebarsko, p 370 (in Croatian) 
Tomov R (2003) Phyllonorycter robiniella (Clemens, 1859) (Lepidoptera, Gracillariidae), new pest on Robinia pseudoacacia L. in Bulgaria. In: Scientific papers of the international scientific conference "50 years of University of Forestry". Session plant protection. University of Forestry, Sofia, pp 105-107 (in Bulgarian)

Torelli N (2002) Black locust (Robinia pseudoacacia L.) and its wood. Les 54:6-10 (in Slovenian)

Trenchev G, Pelov V, Tomov R (1993) Parectopa robiniella (Clemens) (Gracillariidae), pest on Robinia pseudoacacia L. in Bulgaria. In: National scientific-technical conference of Forest protection, 30 March 1993, Sofia. University of Forestry, Sofia, pp 100-107 (in Bulgarian)

Tu B, Gavaland A, Du K, Lu X (2007) Black locust in China. For-ENT 177:50-53 (in French)

Vajda Z (1974) The science of forest protection. Školska knjiga, Zagreb, p 482 (in Croatian)

Vakulyuk PG (1991) Stories about the trees. Kyiv, Urozhay, p 296 (in Ukrainian)

Vakulyuk PG, Samoplavskyy VI (1998) Forest renewal and afforestation in plain regions of Ukraine. Fastiv, Polyphastic, p 508 (in Ukrainian)

Van Loo M, Milcevicova R, Westergren M (2017) Robinia pseudoacacia. Silv Slov 151:40-46

Vilà M, Başnou C, Gollasch S, Josefsson M, Pergl J, Scalerra R. 2009. One hundred of the most invasive alien species in Europe In: DAISIE (ed) DAISIE handbook of alien species in Europe invading nature, (Springer series in invasion ecology, vol. 3). Dordrecht: Springer., pp 265-268

Vítková M (2011) Black locust growth management. Cas Ochr Pri 6:7-12 (in Czech)

Vítková M, Kolbek J (2010) Vegetation classification and synecology of Bohemian Robinia pseudacacia stands in a Central European context. Phyto 2-3:205-241

Vítková M, Tonika J, Müllerová J (2015) Black locust—successful invader of a wide range of soil conditions. Sci Total Environ 505:315-328

Vítková M, Pergl J, Sádlo J (2016) Black locust: from global ecology to local management-a case study from the Czech Republic. In: Krumm F, Vítková L (eds) Introduced tree species in European forests: opportunities and challenges. European Forest Institute, Freiburg, pp 306-318

Vítková M, Müllerová J, Sádlo J, Pyšek P (2017) Black locust (Robinia pseudoacacia) beloved and despised: a story of an invasive tree in Central Europe. For Ecol Manag 384:287-302

Vlase I (1982) Conservation of forest seeds. Editura Ceres, București, p 278 (in Romanian)

Vor T, Spellmann H, Bolte A, Ammer C (eds) (2015) Potentials and risks of introduced tree species. Göttinger Forstwissenschaften 7, Göttingen, p 296

Vuković N, Filipas M, Jelaska S (2013) The overview of the invasive behavior of black locust (Robinia pseudoacacia L.) in Croatia. In: Alegro A, Boršić I (eds) Book of abstracts, 4th Croatian botanical conference with international participation. Croatian Botanical Society, Velika Gorica, pp 207-208 (in Croatian)

Węgorek T, Kraszkiewicz A (2005) Growth dynamics of black locust (Robinia pseudacacia L.) in middle-field shelterbelt on loess soils. Act Agric 1:211-218 (in Polish)

Wojda T, Klisz M, Jastrzębowski S, Mionskowski M, Szyp-Borowka I, Szczygieł K (2015) The geographical distribution of black locust (Robinia pseudoacacia L.) in Poland and its role in non-forest land. P Gl Ch-IGBP 22:101-113

Wraber M (1951) Non-native tree species in our forests. Gozd vest 9:94-103 (in Slovenian)

Zajączkowski K (2013) Silviculture. Plantations of fast-growing trees. PWRiL, Warszawa, p 168 (in Polish)

Zajączkowski K, Wojda T (2012) Black locust Robinia pseudoacacia L. in economic cultivation. St Mat CEPL Rog 14:130-135 (in Polish)

Zucchini A (1800) On the cultivation and uses of black locust, or Robinia pseudoacacia Lin., tree that grows early and forms hard and colorful wood: lecture provided on 7 August this year 1800. Ed. Cambiagi Gaetano, Firenze, p 27 (in Italian)

Publisher's Note Springer Nature remains neutral with regard to jurisdictional claims in published maps and institutional affiliations. 